\title{
CENOZOIC POST-BREAKUP COMPRESSIONAL DEFORMATION AND EXHUMATION OF THE SOUTHERN AUSTRALIAN MARGIN
}

\author{
S.P. Holford ${ }^{1}$, R.R. Hillis ${ }^{2}$, I.R. Duddy ${ }^{3}$, P.F. Green ${ }^{3}$, M.S. Stoker ${ }^{4}$, A.K. Tuitt ${ }^{1}$, G. Backé ${ }^{1}$, D.R. Tassone ${ }^{1}$ and \\ J.D. MacDonald ${ }^{1}$ \\ ${ }^{1}$ Centre for Tectonics, Resources and Exploration (TRaX), Australian School of Petroleum, University of Adelaide, \\ North Terrace, Adelaide, SA 5005 \\ ${ }^{2}$ Deep Exploration Technologies Cooperative Research Centre, University of Adelaide, North Terrace, Adelaide, \\ SA 5005 \\ ${ }^{3}$ Geotrack International Pty Ltd, 37 Melville Road, Brunswick West, Vic 3055 \\ ${ }^{4}$ British Geological Survey, Murchison House, West Mains Road, Edinburgh, EH9 3LA, UK
}

simon.holford@adelaide.edu.au

rhillisdetcrc@gmail.com

mail@geotrack.com.au

mail@geotrack.com.au

mss@bgs.ac.uk

adrian.tuitt@adelaide.edu.au

david.tassone@adelaide.edu.au

justin.macdonald@adelaide.edu.au

guillaume.backe@adelaide.edu.au

\begin{abstract}
We present results from a margin-wide analysis of the history of post-breakup Cenozoic compressional deformation and related exhumation along the passive southern margin of Australia based on a regional synthesis of seismic, stratigraphic and thermochronological data. The Cenozoic sedimentary record of the southern margin contains regional unconformities of intraLutetian and late Miocene-Pliocene age, which coincide with reconfigurations of the boundaries of the Indo-Australian Plate. Seismic data show that post-breakup compressional deformation and sedimentary basin inversion, characterised by reactivation of syn-rift faults and folding of post-rift sediments, is pervasive from the Gulf St Vincent to Gippsland basins, and occurred almost continually since the early-to-mid Eocene. Inversion structures are absent from the Bight Basin which we interpret to be the result of both the unsuitable orientation of faults for reactivation with respect to post-breakup stress fields, and the colder, stronger lithosphere that underlies that part of the margin. Compressional deformation along the southeastern margin has mainly been accommodated by reactivation of syn-rift faults resulting in folds with varying ages and amplitudes within the post-rift Cenozoic succession. Many hydrocarbon fields in the Otway and Gippsland basins are located within these folds, the largest of which are often associated with substantial localised exhumation. Our results emphasise the importance of constraining the timing of Cenozoic compression and exhumation in defining hydrocarbon prospectivity of the southern margin.
\end{abstract}

\section{KEYWORDS}

Australia, passive margins, stratigraphy, uplift, inversion, compressional deformation, folding, faulting, stress, AFTA.

\section{INTRODUCTION}

The physiography, geological record and hydrocarbon resources of the passive continental margin of southern Australia (Fig. 1) largely represent the legacy of late Jurassic to early Paleogene crustal and lithospheric extension and thinning that resulted in final separation of Australia and Antarctica during the mid-Eocene, around 43 million years ago (Fig. 2) (Norvick and Smith, 2001). In addition, the opening of the Tasman Sea during the late Cretaceous to mid-Eocene (Gaina et al., 1998) strongly influenced the geological development of eastern parts of the margin. This extensional deformation allowed a series of fault-controlled depocentres to develop along the southern margin of Australia (Norvick and Smith, 2001), with total thicknesses of Cretaceous-Cenozoic sedimentary successions in the Bight, Otway and Gippsland Basins exceeding $10 \mathrm{~km}$ (Blevin and Cathro, 2008). Particularly along the southeastern parts of the margin, where intensive onshore and offshore hydrocarbon exploration has been conducted for more than 40 years, these sedimentary depocentres contain economically significant oil (Gippsland Basin), conventional gas (Gippsland and Otway basins) and brown coal (Gippsland Basin) reserves 
(Geoscience Australia and ABARE, 2010), and are targets for $\mathrm{CO}_{2}$ storage (Cook, 2009) and future geothermal and shale gas exploration (Backé et al., 2011). In contrast, no significant hydrocarbon resources have been identified along the underexplored western and central parts of the margin (e.g. the Bight Basin; Totterdell and Bradshaw, 2004), although many prospective deepwater plays are yet to be tested by drilling (MacDonald et al., 2010).

As is the case with many passive continental margins around the world (e.g. Bond and Kominz, 1988), nearly all previous research into the tectonic evolution of the southern Australian margin has primarily concentrated on understanding the nature of the Cretaceous and early Paleogene rifting episodes which occurred prior to final separation from Antarctica (Lister et al., 1991; Norvick and Smith, 2001). In general, most models for passive margin evolution imply that no significant deformation is likely to occur subsequent to final continental separation, with post-breakup histories commonly perceived as being characterized by tectonic quiescence and uninterrupted, gradually decaying subsidence (Praeg et al., 2005). However, as global hydrocarbon exploration has increasingly focused on passive margins, it has become apparent that the geological records of many margins contain evidence of considerably more dynamic post-breakup tectonic evolution. Passive margins including those which bound NW Europe (Stoker et al., 2005; Holford et al., 2009a), West Africa (Hudec and Jackson, 2002; Turner et al., 2008) and Brazil (Cobbold et al., 2001) contain evidence for spatially and temporally variable compressional deformation (e.g. basin inversion), and anomalous phases of subsidence, and uplift and exhumation that have occurred subsequent to continental breakup. Numerous processes related to plate and mantle dynamics have been invoked to explain observations of atypical postbreakup tectonic behaviour (Praeg et al., 2005; Doré et al., 2008), but there is no clear consensus as to the principal driving mechanisms of post-breakup deformation, uplift and exhumation. Identifying and understanding these driving mechanisms is not only a fundamental tectonic problem, but also has significant implications for hydrocarbon exploration, since the timing of post-breakup trap formation in relation to thermal evolution is a major uncertainty associated with the geological development of passive margins (White et al., 2003).

Over the past few decades, studies of the Cenozoic sedimentary record of the southern Australian margin have revealed a similar record of temporally and spatially variable post-breakup compressional deformation, uplift and exhumation (Etheridge et al., 1991; Hill et al., 1995; Dickinson et al., 2001; Green et al., 2004; Sandiford et al., 2004; Hillis et al., 2008). Some of the most striking evidence for atypical post-breakup tectonic behaviour includes the identification of reverse-faulting and folding of Cenozoic sediments in onshore and offshore parts of the southeastern margin (Hill et al., 1995; Dickinson et al., 2001; Sandiford, 2003a); widespread seismicity with reverse-oblique earthquake focal mechanisms implying ongoing deformation of the margin, at rates considerably higher than observed in comparable continental regions located far from plate boundaries (Clark and Leonard, 2003; Célérier et al., 2005; Hillis et al., 2008); evidence from depth-of-burial studies of Cretaceous and Cenozoic sediments using compactional and thermochronological methods for substantial localised post-breakup exhumation (Green et al., 2004; Holford et al., 2010; Tassone et al., 2010); and, the occurrence of Neogene palaeoshorelines at elevations of $\leq 250 \mathrm{~m}$ above present-day sea level, up to many hundreds of kilometres inland of the present-day coastline, implying widespread onshore surface uplift (Sandiford, 2007).

Although a number of studies have suggested that the observations of post-breakup deformation and uplift of the southern Australian margin described above can largely be understood in terms of intraplate responses to plate boundary forcing, and dynamic topographic responses to variations in mantle structure (e.g. Dyksterhuis and Müller, 2008; Hillis et al., 2008; Sandiford and Quigley, 2009), these investigations have largely focused on the late Miocene-Recent geological record, and there is less certainty as to how the older (i.e. earlyEocene to early Miocene) record of deformation and uplift relates to the broader geodynamic evolution of the Indo-Australian Plate. There is also no clear consensus as to what factors serve to localise post-breakup deformation and uplift in both space and time (Hillis et al., 2008). Establishing a better understanding of the post-breakup tectonic evolution of the southern Australian margin is of profound importance for focussing future hydrocarbon exploration. Many of the largest oil and gas accumulations along the southern margin are hosted in traps that formed during post-breakup compressional deformation (Hillis et al., 2008), and it has been demonstrated that the relative timing of post-breakup trap formation and uplift in relation to source rock maturation is a critical control on prospectivity (Holford et al., 2010). In order to better understand the chronology, distribution and driving mechanisms of post-breakup deformation, uplift and exhumation, we have been conducting a margin-wide synthesis of seismic, stratigraphic and thermochronological data from the southern margin. In contrast to the majority of previous studies, which have tended to focus on either specific geographic areas or distinct time intervals, we have investigated the mid-Eocene onwards record of deformation and uplift from the Bight Basin in the west, to the Gippsland basin in the east. Here we present initial results from this ongoing synthesis. Following a review of the evidence for post-breakup tectonic activity in each of the major depocentres along the margin, we then identify a number of margin-wide events and discuss both their potential relationship with key tectonic events in the evolution of the Indo-Australian Plate, and some of that factors that might serve to localise post-breakup deformation in both space and time.

\section{POST-BREAKUP DEFORMATION AND EXHUMATION}

Here we summarise the evidence for post-breakup compressional deformation, uplift and exhumation in the major onshore/offshore sedimentary depocentres of the southern Australian margin - from west to east, the Bight and Eucla basins, the St Vincent Basin, the Otway Basin, the Torquay sub-basin, the Bass Basin and the Gippsland Basin (Fig. 1). Although we recognise that seafloor spreading initiated south of the Bight Basin during the late Albian-early Campanian ( 95-83 Ma) (Tikku and Cande, 1999; Sayers et al., 2001), this paper is concerned with the record of deformation, uplift and exhumation from early-Eocene times onwards. We define two key events that marked the onset of the post-breakup stage of the southern margin's evolution. These are the cessation of seafloor spreading east of Australia in the Tasman Sea at $~ 53 \mathrm{Ma}$ (Gaina et al., 1998), and the final separation of Australia and Antarctica and onset of fast-spreading in the Southern 
Ocean at $\sim 43 \mathrm{Ma}$ (Norvick and Smith, 2001). By the early-mid Eocene, major normal faulting had ceased along much of the margin (Blevin and Cathro, 2008), indicating the waning on the extensional stress field that had dominated the tectonic evolution of the margin since late Jurassic times.

Our summary is based on a review of existing studies, combined with our own field observations and analysis of seismic, stratigraphic and thermal history data. We have assembled a comprehensive dataset comprising stratigraphic data and geophysical logs from hundreds of onshore and offshore wells supplied by state and national geological surveys, 2D seismic data with total line-length of over $120,000 \mathrm{~km}$ provided through the PGS Southern Australian Margin Digital Atlas (SAMDA), and apatite fission-track analysis (AFTA) and vitrinite reflectance (VR) data from over 50 wells, bestowed by Geotrack International Pty Ltd.

\section{Bight and Eucla Basins}

The Bight Basin system covers an area of $>800,000 \mathrm{~km}^{2}$ with onshore sediments extending $400 \mathrm{~km}$ north of the present-day coast and offshore in water depths of $>5 \mathrm{~km}$ (Fig. 1). The basin is largely unexplored, with only 13 wells drilled during offshore hydrocarbon exploration, though Ocean Drilling Program (ODP) Leg 182 drilled 27 holes at 9 sites near the Jerboa-1 well in the western part of the basin (Feary et al., 2000). It comprises a series of depocentres which include the Eyre, Duntroon, Ceduna and Recherche sub-basins, that formed during middle-late Jurassic to early Cretaceous N-S to NW-SE directed extension (Totterdell and Bradshaw, 2004). Normal faults predominantly strike ENE-WSW in the Eyre sub-basin, and E-W and ESE-WNW in the Ceduna and Duntroon sub-basins (Totterdell and Bradshaw, 2004). The main phase of extensional deformation was followed by major sediment accumulation during late Cretaceous deltaic progradation which resulted in gravity-driven extensional and compressional deformation, particularly in the Ceduna sub-basin (Totterdell and Krassay, 2003; MacDonald et al., 2010). The Mesozoic sediments, which primarily comprise sands and shales, are unconformably overlain by the post-breakup, Cenozoic Eucla Basin (Totterdell and Bradshaw, 2004). Seismic data collected from the Madura Shelf show that this regional unconformity is angular in nature, and that underlying latest Cretaceous units have been progressively eroded across the shelf (Totterdell and Bradshaw, 2004). Available biostratigraphic information suggests that the unconformity represents an age gap of $\sim 5-7$ Myr, with the oldest units of the overlying Eucla Basin succession dated as late Paleocene age ( $\sim 58 \mathrm{Ma}$; Totterdell et al., 2000; Fig. 2). This unconformity has been associated with the final stage of separation between Australia and Antarctica along this portion of the southern margin (Bradshaw et al., 2003). Schofield and Totterdell (2008) have recently described a $\sim$ NW-SE trending igneous field covering an area of $\sim 50,000 \mathrm{~km}^{2}$ comprising numerous volcanic and intrusive bodies from the Ceduna sub-basin and Eucla Basin. Direct age constraints on this igneous field are not available, though Schofield and Totterdell (2008) infer a mid-Eocene age based on correlation of dated seismic marker horizons.

The Eucla Basin extends $\sim 2000 \mathrm{~km}$ from west to east and $\sim 500 \mathrm{~km}$ from north to south, thereby constituting the largest Cenozoic basin on the southern margin (Hou et al., 2006, 2008). Though extensive, the Eucla Basin succession is relatively thin (up to $800 \mathrm{~m}$ ) (James et al., 2006). Lower parts of the Eucla Basin succession are siliciclastic units with interbedded lignites deposited in nearshore environments, and from middle Eocene times onwards the succession becomes progressively more dominated by carbonates, with deposition of occasional marine clastic units (Hou et al., 2006). Seismic data show that the offshore succession is largely planar and undeformed, with no evidence for reverse faulting or folding (Fig. 3). The basal sequence boundary forms a major onlap surface, implying an increase in subsidence-rate during the mid-Eocene, possibly in response to the contemporaneous increase in seafloor spreading rate (Totterdell et al., 2000). Drilling of the offshore succession of the Eucla Basin above the Eyre sub-basin during ODP Leg 182 documented near-continual carbonate accumulation from mid-Eocene ( $\sim 3 \mathrm{Ma}$ ) onwards, although individual sediment packages were discovered to be bound by unconformities (Li et al., 2003, 2004). Within the Middle-Upper Eocene succession, Li et al. (2003) identified unconformities at $\sim 43,39,37$ and $34 \mathrm{Ma}$, coinciding with four major third-order sequence boundaries (Fig. 2). These unconformities were interpreted to record regional sea-level changes driven by a series of rapid changes in Southern Ocean seafloor spreading rates (Li et al., 2003). In a similar study of the Neogene succession recovered during ODP Leg 182, Li et al. (2004) identified three major hiatuses at $\sim 16-15,8-9$ and 2.5-1.5 Ma, with the Miocene hiatuses having durations of $<5 \mathrm{Myr}$ at selected sites (Fig. 2). Li et al. (2004) argued that these hiatuses more likely represented sediment removal than non-deposition, and attributed their origin to large-scale slope-failure driven by differential uplift and subsidence.

The onshore sedimentary succession of the Eucla Basin comprises a series of unconformity-bound carbonate packages: the Middle to Upper Eocene Wilson Bluff Limestone, the Upper Oligocene to Lower Miocene Abrakurrie Limestone, and the Middle Miocene Nullarbor Limestone (James et al., 2006). A number of recent studies have identified post-breakup uplift and tilting of these sediments through examination of palaeo-shoreline associated with carbonate deposition that are preserved on the Nullarbor Plain (Fig. 4) (Hou et al., 2006, 2008; Sandiford, 2007). Sandiford (2007) reports the occurrence of mid-late Eocene ( 41-39 Ma) palaeo-shoreline features including offshore barrier systems, marginal lagoons and inundated valleys that extend up to $\sim 400 \mathrm{~km}$ inland of the present-day shoreline. Along the northwestern Eucla Basin margin, maximum marine flooding occurred at $\sim 39$ Ma to levels that are now $\sim 300 \mathrm{~m}$ above sea level (ASL) (Sandiford, 2007). However in the eastern Eucla Basin, similarly aged shorelines are significantly lower (as low as $\sim 160 \mathrm{~m} \mathrm{ASL}$ ), implying a minimum $\sim 140 \mathrm{~m}$ differential across the $\sim 1000 \mathrm{~km}$ wide Nullarbor Plain (Sandiford, 2007). Early-mid Miocene $(<15 \mathrm{Myr})$ shorelines associated with deposition of the Nullarbor Limestone are systematically lower than the older Eocene shorelines by between 30 and $80 \mathrm{~m}$ (Hou et al., 2006). The elevations of these shorelines show a similar variation across the Nullarbor Plain, with maximum elevations in the central west part of the basin along the northernmost limit of the Plain at $\sim 250 \mathrm{~m} \mathrm{ASL}$, then systematically dropping eastwards to $\sim 100 \mathrm{~m}$ ASL (Sandiford, 2007). The similarity between the differential, long-wavelength $(\sim 1000 \mathrm{~km})$ displacement of the Eocene and Miocene shorelines across the Nullarbor Plain suggests that the relative west-up tilting occurred subsequent to the deposition of the Nullarbor 
Limestone (i.e. after $15 \mathrm{Ma}$ ) (Sandiford, 2007). The preservation of the Eocene and Miocene shorelines indicates that uplift was not accompanied by exhumation. The youngest sedimentary unit of the onshore Eucla Basin is the Upper Pliocene Roe Calcarenite, a $\sim 2-3 \mathrm{~m}$ thick quartzose molluscan sand (James et al., 2006). The Roe Calcarenite underlies the Roe Plains, an arcuate $\sim 300 \mathrm{~km}$ wide platform that rises from sea level to a height of $\sim 30 \mathrm{~m}$ at Madura (Fig. 4) (James et al., 2006). The Roe Plains are bounded by the Eucla cliffs and are the calcarenite is interpreted to lie on a marine erosion surface cut into the Abrakurrie and Nullarbor Limestones (James et al., 2006). James et al. (2006) ascribe the preservation of the Roe Plains to their uplift immediately after deposition, and suggest that the uplift correlates with the $2.5-1.5$ Ma hiatus described from ODP Leg 182 by Li et al. (2004).

Whilst the onshore and offshore Eucla Basin contains abundant evidence of regional long-wavelength post-breakup uplift, there is considerably less indication of significant post-breakup compressional deformation. Digital elevation data show that a number of minor faults that mostly trend NNW and NNE have displaced the surface of the Nullarbor Plain (Hou et al., 2008). These trends are approximately orthogonal to the inferred E-W orientation of the present-day stress field in the Eucla Basin (Hillis et al., 2008). The observation that these minor faults displace the Nullarbor Limestone but not the Roe Calcarenite implies that they formed between $\sim 15$ and $4 \mathrm{Ma}$ (Hou et al., 2008). The heights of scarps associated with these faults imply throws of up to 15-20 m (Fig. 4) (Hillis et al., 2008), implying long-term displacement rates of $<2 \mathrm{~m} \mathrm{Myr}^{-1}$.

\section{St Vincent Basin}

The St Vincent Basin is a small Cenozoic depocentre located between the Yorke Peninsula and the Mt Lofty Ranges in South Australia (Fig. 5) containing a relatively thin (up to $700 \mathrm{~m}$ ) sedimentary succession (Alley and Lindsay, 1995), which nonetheless provides a number of lines of evidence for post-breakup deformation and uplift. The basin is a $\sim$ NNE-SSW oriented graben bounded by folded and faulted Proterozoic and Palaeozoic rocks, and its structure is strongly influenced by basement fabrics associated with the Delamerian fold belt (Alley and Lindsay, 1995; Flöttmann and Cockshell, 1996). The Cenozoic sediments overlie Cambrian metasediments and Permian glacial deposits, with Mesozoic sediments absent (Alley and Lindsay, 1995). The oldest unit of the basin is the non-marine Middle Eocene age North Maslin Sand (Alley and Lindsay, 1995). Succeeding formations of Middle Eocene-Middle Miocene age comprise a combination of sands and clays with lignite lenses, and marls and limestones that witness the increasing influence of marine depositional environments (Alley and Lindsay, 1995). The Oligocene-Middle Miocene Port Willunga Formation is separated from the overlying Pliocene age Hallett Cove Sandstone and younger units by an angular unconformity of mid-Miocene-early Pliocene age that occurs throughout the basin, and is locally associated with up $\sim 100 \mathrm{~m}$ of erosion (Sandiford et al., 2004).

The St Vincent Basin is bounded on both margins by numerous faults that display evidence for post-breakup displacement (Fig. 5). On the eastern margin of the basin, the Mt Lofty Ranges (maximum elevation $\sim 700 \mathrm{~m}$ ) are bounded by a series of discrete, curvilinear faults with prominent scarps, including (from north to south) the Para Fault, the Eden-Burnside Fault, the Ochre Cove Fault and the Willunga Fault (Sandiford, 2003a). The lack of degradation of these scarps attests to the youthful nature of the topography and drainage systems in the Mt Lofty Ranges (Sandiford, 2003a). Although the faults are mostly buried beneath alluvial fans and associated pediments (Sandiford, 2003a), the Willunga Fault is exposed at Sellicks Beach (Fig. 6), where a major fault-contact with inferred reverse displacement juxtaposes metamorphosed Cambrian sediments against Quaternary alluvial fan deposits (Sandiford, 2003a). The shallow-dipping Port Willunga Formation progressively steepens towards the fault, with dips of limestone beds reaching $\sim 60^{\circ}$ at a wave-cut platform in the footwall, where they are overlain with marked unconformity by late Pleistocene alluvium (Sandiford, 2003a). The differential elevation of Port Willunga Formation deposits that occur in the hangingwall and footwall implies post-early Miocene movement of $\sim 240 \mathrm{~m}$ on the Willunga Fault. Seismic reflection profiles acquired within Gulf St Vincent show evidence for mild deformation of Cenozoic sediments adjacent to the offshore continuation of the Willunga Fault (Fig. 7).

Both the Mt Lofty Ranges, and the contiguous Flinders Ranges further to the north (where there is also abundant evidence for MioceneQuaternary faulting; Quigley et al., 2006) are characterised by high levels of seismicity (Célérier et al., 2005), suggesting that post-breakup deformation in these areas is ongoing. Sandiford et al. (2004) calculate seismogenic strain rates of $\sim 10^{-16} \mathrm{~s}^{-1}$ for the Flinders Ranges based on recorded earthquake activity from 1970 to 2003. These rates are several orders of magnitude higher than calculated for the entire Australian continent and for comparable intraplate regions (Célérier et al., 2005; Hillis et al., 2008). Focal mechanisms determined for Flinders Ranges earthquakes indicate reverse and strike-slip mechanisms and an approximately E-W oriented maximum horizontal stress orientation (Greenhalgh et al., 1994; Clark and Leonard, 2003). These observations suggest that the Flinders and Mt Lofty Ranges are undergoing crustal shortening, consistent with the evidence for post-breakup reverse-faulting along the margins of the St Vincent Basin.

\section{Otway Basin}

The Otway Basin is a large, broadly NW-SE trending basin that encompasses onshore and offshore parts of South Australia and Victoria and extends into Tasmanian waters (Fig. 8) (Krassay et al., 2004). It covers an area of $\sim 150,000 \mathrm{~km}^{2}$ and contains sediments and subsidiary volcanic rocks of late Jurassic-Recent age. Both the stratigraphy and structure of the basin have been studied extensively (e.g. Boult \& Hibburt, 2002; Duddy, 2003; Holdgate and Gallagher, 2003; Krassay et al., 2004) and there has been extensive onshore and shallow water $(<500 \mathrm{~m})$ hydrocarbon exploration. There have been commercial hydrocarbon discoveries onshore South Australian in the Penola Trough, where several small gas accumulations have been produced from the Lower Cretaceous Pretty Hill Formation, and in the Port Campbell area in Victoria where numerous gas accumulations have been discovered within the regional Upper Cretaceous Waarre Formation 
reservoir interval. The largest gas discoveries in this part of the basin have been made offshore in the Shipwreck Trough, with the combined reserves of the Geographe and Thylacine fields estimated at $\sim 1.3 \mathrm{TCF}$.

The basin was initiated during $\sim \mathrm{N}-\mathrm{S}$ extension in the late Jurassic, which produced a series of $\sim \mathrm{E}-\mathrm{W}$ to $\sim \mathrm{NW}$-SE trending half-grabens. These structurally-controlled depocentres expanded significantly as extension progressed throughout the early Cretaceous, during which time they were filled with $>5 \mathrm{~km}$ of fluvio-lacustrine Otway Group sediments (Cooper and Hill, 1997). During the late Albian, the basin experienced widespread compression and inversion resulting in a regional, angular mid-Cretaceous unconformity (Hill et al., 1995; Duddy, 2003; Krassay et al., 2004). Inversion was most intense in eastern parts of the basin, with substantial localised exhumation (up to $3 \mathrm{~km}$ ) accompanying deformation in parts of the Otway Ranges (Cooper and Hill, 1997; Duddy, 2003; Green et al., 2004; Tassone et al., 2010). Renewed extension and subsidence commenced in the Turonian, with various authors arguing for continued $\sim \mathrm{N}-\mathrm{S}$-directed extension (Krassay et al., 2004) or a switch to more oblique $\sim$ NE-SW-directed extension (Schneider et al., 2004). The locus of extension shifted to the south, and normal displacements along a series of $\sim \mathrm{NW}$-SE-striking fault systems produced a series of major late Cretaceous depocentres that includes the Voluta and Shipwreck Troughs (Krassay et al., 2004). The syn-rift Upper Cretaceous Sherbrook Group contains a series of prograding delta complex sediment packages, and attains a thickness of $>5 \mathrm{~km}$ (Duddy, 2003).

A major regional unconformity of intra-Maastrichtian age marks the cessation of major extensional tectonics in the Otway Basin (Krassay et al., 2004), though interpretations of magnetic data from south of Tasmania suggest that first oceanic crust did not form off the Otway Basin until the mid-Eocene (Royer and Rollet, 1997; Norvick and Smith, 2001). The Cenozoic sedimentary succession contains three distinct megasequences that are separated by major regional unconformities. The siliciclastic progradational deposits of the latest Maastrichtian to Middle Eocene Wangerrip Group are separated from the overlying Upper Eocene to Lower Oligocene Nirranda Group by a regional intra-Lutetian unconformity (Holdgate and Gallagher, 2003). The Nirranda Group comprises nearshore to offshore clastics and open marine carbonates, and is separated from the overlying Upper Oligocene to Upper Miocene Heytesbury Group by a regional intraOligocene unconformity (Holdgate and Gallagher, 2003). The Heytesbury Group mostly comprises open marine carbonates, and the top of the group is marked by a regional late Miocene unconformity (Dickinson et al., 2002). Relatively thin and localised mixed siliclasticcarbonate sediments and basaltic volcanic rocks unconformably or disconformably overlie the Heytesbury Group succession.

Although an increasing number of studies have recognised the significance of post-breakup deformation, uplift and exhumation within the Otway Basin (e.g. Duddy, 1994; Hill et al., 1995; Perincek and Cockshell, 1995; Dickinson et al., 2002; Sandiford, 2003a; Green et al., 2004; Wallace et al., 2005), most of this work has focussed on the record of tectonic activity from the late Miocene onwards. However, the integration of seismic, stratigraphic and thermochronological data from the basin reveals evidence for important phases of deformation earlier in the Cenozoic. Figure 9 shows a regional, approximately margin-parallel seismic line that extends from the Morum-1 and Troas-1 wells in the northwestern part of the basin, to the Loch Ard-1 well towards the southeast. The interpretation is constrained by regional seismic mapping of the unconformities that bound the Cenozoic megasequences using the PGS SAMDA database. The Wangerrip megasequence, which is bound by the intra-Maastrichtian and intra-Lutetian unconformities clearly thins towards the Morum structural high in the northwest of the basin, and underlying reflections clearly define this structure as a faulted anticline with a wavelength of $\sim 20$ $\mathrm{km}$, and a classic inversion structure (cf. Williams et al., 1989; Holford et al., 2009b). Additional constraints on the formation of this structure are provided by thermochronological (AFTA, VR and apatite (U-Th)/He) and stratigraphic data from the Morum-1 well (Duddy et al., 2003). Morum-1 intersected a thin package of Palaeocene-age (L. balmei) Wangerrip Group sediments, and seismic data to the NE of the well indicate that Wangerrip Group foresets onlap the intra-Maastrichtian unconformity (Duddy et al., 2003). Thermal history reconstruction indicates that the preserved Wangerrip Group sediments, and the thick underlying Upper Cretaceous succession drilled by Morum-1 were more deeply buried by $\sim 1.5 \mathrm{~km}$ of additional Wangerrip sediments that were removed during uplift and exhumation that accompanied growth of the Morum structure and commenced between 57 and $40 \mathrm{Ma}$ (Duddy et al., 2003). The thickness of the putative Wangerrip Group succession removed from the Morum structure is similar to that which is still preserved in the Portland Trough to the SE $(>1.5 \mathrm{~km}$ ) (Holdgate and Gallagher, 2003). After allowing for the time period required for $\sim 1.5 \mathrm{~km}$ of Wangerrip Group sediments to accumulate, Duddy et al. (2003) proposed that exhumation at Morum-1 most likely began between $\sim 45$ and 40 Ma, consistent with the age of the regional intra-Lutetian unconformity that marks the top of the Wangerrip Group. AFTA data from the nearby Copa-1, which was also drilled into an inversion anticline, provide evidence for similarly timed mid-Eocene uplift of this structure (Fig. 2). The regional seismic profile in Figure 9 also shows recurrent thinning of the Wangerrip Group towards the Minerva-1 and Loch Ard-1 wells, and AFTA and VR data from the nearby Mussel-1 well provide evidence for uplift and exhumation of probable mid-Eocene age in this part of the basin (Duddy and Erout, 2001; Duddy et al., 2003).

In addition to the evidence it provides for mid-Eocene deformation, Fig. 9 shows that the sediments within the Nirranda and Heytesbury Groups have also been variably folded, providing clear evidence for younger phases of post-breakup compressional deformation within the Otway Basin. Seismic mapping enables the identification of a series of $\sim$ NE-SW trending anticlines within the offshore basin, some of which may be connected to onshore folds with similar trends that have been identified from onshore seismic mapping and field observations (Fig. 8). For example, the Minerva Anticline that hosts the Minerva gas field (Holford et al., 2010) may extend onshore to join the Ferguson Hill Anticline (Sandiford, 2003a). Tuitt et al. (2011) describe these anticlines in more detail in an accompanying paper in this volume, and the chronologies of their growth will be addressed in detail elsewhere, but to summarise, most appear to have formed following reverse displacements on faults that formed during Cretaceous extension. The timing of growth of these anticlines varies from mid-Eocene to Pliocene, implying near continual post-breakup fault reactivation and folding. Onshore mapping of Cenozoic sediments indicates that in addition to reactivation of existing faults, post-breakup deformation in the Otway Basin was also accommodated by the initiation of new reverse-faults (Fig. 10).

Although post-breakup faulting and folding in the Otway Basin appears to have occurred more or less continually since the mid-Eocene, 
there is a clear peak in tectonic activity during the late Miocene-early Pliocene, coeval with the development of the regional unconformity of this age (Dickinson et al., 2002; Sandiford et al., 2004). Compressional deformation and uplift were particularly intense around the Otway Ranges, a large NE-SW-oriented outlier of Eumeralla Formation sediments located in the eastern Otway Basin (Hill et al., 1995; Cooper and Hill, 1997). The Otway Ranges reach an elevation of $\sim 670 \mathrm{~m}$, and having witnessed major uplift and exhumation during the mid-Cretaceous (e.g. Duddy, 1994, 1997, 2003), this age of topography is often assumed to date back to this time. However, several lines of evidence indicate these uplands are a much younger feature. Field mapping (e.g. Tickell et al., 1992; Fig. 10) and seismic data (e.g. Hill et al., 1995; Holford et al. in review) indicate that many faults around the Ranges accumulated reverse-displacement during late Cenozoic crustal shortening that reached at least 5\% (Cooper and Hill, 1997). It has been difficult to constrain the amount of uplift and exhumation that accompanied shortening using techniques such as AFTA because of the extent to which the thermal histories of Eumeralla Formation rocks that crop out in the Ranges are dominated by elevated early Cretaceous palaeogeothermal gradients (Duddy, 1994). However, VR data from an isolated inlier of Palaeocene sediments that crops out at Benwerrin (present-day elevation $\sim 300 \mathrm{~m}$ ) indicate reflectance values of $0.40 \%$ (Cooper and Hill, 1997). These VR values imply that this part of the Otway Ranges may have been buried by $\sim 1$ to $1.5 \mathrm{~km}$ prior to uplift and exhumation, and balanced restoration of a regional cross-section through the Otway Ranges performed by Cooper and Hill (1997) indicates that this estimate of deeper burial is structurally plausible. A possible minimum constraint on the age of the Ranges is provided by strandlines of probable Pliocene age located to the NW that exhibit pronounced curvature as they approach the Ranges, suggesting their prior existence (Wallace et al., 2005). Subsequent post-early Pliocene uplift of the NW Otway Ranges is also inferred on the basis of the present-day elevation of a pronounced Pliocene shoreline at $\sim 230-280 \mathrm{~m}$ ASL (Sandiford, 2003a). By analogy with correlative systems in the Murray Basin, Sandiford (2003b) inferred between 175 and $240 \mathrm{~m}$ of post-early Pliocene uplift of the Otway Ranges, attributed to displacement along blind faults.

\section{Torquay sub-basin}

The Torquay sub-basin contains up to $\sim 7 \mathrm{~km}$ of Neogene-Recent sediments, and is bounded to the NW by the Otway Ranges and to the SE by the Mornington Peninsula, both NE-SW trending structural highs that were uplifted during the late Cenozoic (Dickinson et al., 2002). The Torquay sub-basin is defined as part of the Otway Basin, but the post-mid Cretaceous stratigraphy shares closer affinity with the adjacent Bass Basin (Trupp et al., 1994; Messent et al., 1999). The regional mid-Cretaceous unconformity is overlain by the Upper Cretaceous to Middle Eocene age Eastern View Group, which in turn is separated from the overlying Upper Eocene to Lower Oligocene Demons Bluff Group by a regional mid-Eocene unconformity (Messent et al., 1999). The fully marine Oligocene-Miocene Torquay Group is broadly equivalent to the Heytesbury Group, and its top is marked by the regional late Miocene unconformity that is also observed in the Otway Basin (Dickinson et al., 2002). To date there have been no hydrocarbon discoveries in the basin.

Although the Torquay sub-basin is relatively small $\left(\sim 5000 \mathrm{~km}^{2}\right)$ it contains abundant evidence for post-breakup deformation, uplift and exhumation. Seismic profiles acquired near the unsuccessful Wild Dog-1 well show the existence of a clear, angular unconformity between the Eastern View Group and Demons Bluff Group (Trupp et al., 1994), indicating mid-Eocene deformation and uplift across the Snail Terrace, in the southern part of the basin (Fig. 11). More precise constraints on the timing of mid-Eocene deformation are provided by stratigraphic relationships in the Anglesea coalmine (Fig. 12). Holdgate et al. (2001) report an erosional, angular $\left(\sim 5^{\circ}\right)$ unconformity that separates the folded A Group coal seam of the uppermost Eastern View Group from the overlying Boonah Formation (Demons Bluff Group) (Fig. 12). Holdgate et al. (2001) date this unconformity at 40-39 Ma, and suggest that the deformation may relate to initial Cenozoic uplift of the Otway Ranges. The moisture content of the Anglesea coal indicates maximum burial depths of $\sim 500-800 \mathrm{~m}$ (Holdgate et al., 2001). This estimate is broadly consistent with the results of an AFTA, apatite (U-Th)/He and VR study of the nearby Anglesea-1 well (Green et al., 2004), which indicated that $~ 750-950 \mathrm{~m}$ of additional section had been removed from the top Demon's Bluff Group unconformity. The combined modelling of AFTA, apatite (U-Th)/He and VR data allowed Green et al. (2004) to constrain the onset of the uplift and exhumation that removed the additional section to beginning between 12 and $7 \mathrm{Ma}$ (late Miocene).

The timing of the late Miocene exhumation episode identified at Anglesea-1 is highly consistent with the age of the late Miocene-early Pliocene unconformity that occurs throughout the southeastern basins of the margin. Dickinson et al. (2002) present paleontological evidence and strontium isotope ages from the central Otway Basin and the Port Phillip Basin that constrain the minimum age of the unconformity to between $\sim 10$ and 5 Ma. This unconformity is visible on seismic data from the offshore Torquay sub-basin, where underlying Miocene units dip between 1 to $5^{\circ}$ and have commonly been folded prior to erosion (Fig. 11). Offshore seismic mapping has identified a number of broadly $\sim$ NE-SW trending late Miocene anticlines and monoclines (Trupp et al., 1994; Hill et al., 1995; Holford et al., in review). Amongst the largest of these structures is the Nerita Anticline. Seismic data clearly show that this anticline formed in response to reverse reactivation of $\sim \mathrm{NW}$ and $\sim \mathrm{SE}$ dipping normal faults that accommodated the deposition of Otway Group and Eastern View Group sediments (Holford et al., 2010). AFTA, apatite (U-Th)/He and VR data from the Nerita-1 well, which was drilled into this structure but failed to discover hydrocarbons, indicate that the preserved Torquay Group and underlying stratigraphic units were more deeply buried by $\sim 940$ to $1260 \mathrm{~m}$ of additional late Miocene sediments, prior to exhumation that began between 10 and $5 \mathrm{Ma}$ (Holford et al., 2010, in press). The timing of this exhumation is highly consistent with that determined for the nearby Anglesea- 1 well, and confirms that the development of the late Miocene-Pliocene unconformity was locally associated with significant uplift and exhumation (cf. Dickinson et al., 2002).

Not all the post-breakup deformation observed offshore is restricted to the late Miocene. Shallow seismic profiles located immediately adjacent to the Otway Ranges provide spectacular images of the angular late Miocene-early Pliocene unconformity, but also clearly show folding within the overlying Pliocene sediments. Also, Trupp et al. (1994) show that Wild Dog-1 tested a small anticline that formed during the early Oligocene, based on the observation of onlap of lowermost Torquay Group sediments onto the folded top Anglesea Siltstone 
(Demons Bluff Group) horizon.

\section{Bass Basin}

The Bass Basin is an offshore $\sim \mathrm{NW}$-SE oriented extensional basin that covers an area of $>40,000 \mathrm{~km}^{2}$ between Tasmania and Victoria (Blevin et al., 2005). The basin contains $\sim 10 \mathrm{~km}$ of Lower Cretaceous-Recent sediments, and there are extensive Oligocene-Miocene volcanics and Miocene intrusive bodies (Cummings et al., 2004). The basin is moderately explored, with over 35 exploration wells drilled resulting in around ten commercial to sub-economic oil, gas and condensate discoveries (Cummings et al., 2004). The structural evolution of the basin is thought to be generally similar to that described for the adjacent Otway Basin, with episodes of $\sim \mathrm{N}-\mathrm{S}$ directed extension during the latest Jurassic-early Cretaceous and $\sim \mathrm{NE}-\mathrm{SW}$ directed extension during the late Cretaceous (Cenomanian-Campanian) (Cummings et al, 2004). Oblique rifting from the Cenomanian to mid-Eocene was strongly influenced by sinistral opening of the Southern Ocean between Antarctica and Tasmania (Blevin et al., 2005). The basin is separated into two sub-basins defined on the basis of the predominant structural polarity of the faults that bound the half-graben in the basin (Blevin, 2003; Cummings et al., 2004): the Cape Wickham sub-basin in the northwestern part of the basin, where normal faults predominantly dip towards the $\sim \mathrm{SW}$; and the Durroon subbasin, located in the southeastern part of the basin, where the majority of normal faults dip towards the $\sim$ NE. The syn and post-breakup lithostratigraphy of the basin is essentially similar to that of the Torquay sub-basin (Lennon et al., 1999). Major unconformities of intraMaastrichtian and intra-Oligocene age are observed throughout the basin, and there are multiple localised unconformities within the Eocene succession (Blevin et al., 2005).

The Bass Basin has undergone relatively minor post-breakup deformation in comparison to neighbouring basins (e.g. Hill et al., 1995). Deformation has resulted in the formation of large-scale inversion anticlines within the syn and post-breakup successions, which are mainly concentrated in the western and northwestern parts of the basin, i.e. within the Cape Wickham sub-basin (Cummings et al., 2004; Blevin et al, 2005). The largest post-breakup structure is the Cormorant Anticline (Fig. 13), which formed during the earliest mid-Miocene to late Miocene (Blevin et al., 2005). Blevin et al. (2005) describe Miocene and younger inversion west of the Konkon-1 and Seal-1 wells, which was probably related to uplift of the Mornington Peninsula-King Island structural high (cf. Dickinson et al., 2002). Cummings et al. (2004) also report extensive $\sim \mathrm{N}-\mathrm{S}$ oriented strike-slip faulting of late Oligocene to late Miocene age within the Cormorant Trough. They suggested that similarly-timed localised reverse-reactivation of $\sim \mathrm{NW}$-SE trending faults enhanced closure of the Yolla structure, which contains the largest gas and oil accumulations discovered in the Bass Basin to date.

\section{Gippsland Basin}

The Gippsland Basin is one of Australia's most prolific and mature petroleum provinces, with initial proven reserves estimated at $\sim 4$ billion barrels of oil and $\sim 10$ trillion cubic feet of gas (Woollands and Wong, 2001). Many of the major oil and gas accumulations in the basin occur in traps that formed during post-breakup compression, thus illustrating the profound importance of this process to Australia's hydrocarbon endowment. The Gippsland Basin covers a surface area of $\sim 40,000 \mathrm{~km}^{2}$ and is mostly located offshore, though the western part of the basin extends onshore to southeastern Victoria. The basin trends approximately $\sim \mathrm{E}-\mathrm{W}$, and consists of a major depocentre (the Central Deep) containing $\sim 10 \mathrm{~km}$ of Cretaceous-Recent sediments (Woollands and Wong, 2001). The Central Deep hosts several giant oil and gas fields including Barracouta, Snapper, Kingfish, Marlin and Fortescue (Bernecker et al., 2003). Structurally higher platforms and terraces located to both the north and south flank the Central Deep. The $\sim$ E-W trending Rosedale Fault system (Fig. 8) separates the Northern Terrace, which contains the Patricia, Baleen and Sole fields, from the Central Deep, whilst the Darriman and Foster fault systems (both of which strike $\sim \mathrm{E}-\mathrm{W}$ ) separate the Southern Terrace from the Central Deep (Bernecker et al., 2003).

The sedimentary succession of the Gippsland is subdivided into three major groups. The Lower Cretaceous Strzelecki Group was deposited during the first major extensional episode to affect the basin, and comprises volcaniclastic and fluvio-lacustrine sediments (Bernecker et al., 2003), and is equivalent to the Otway Group in the Otway Basin (Duddy, 2003). The Strzelecki Group is succeeded by the Upper Cretaceous to Upper Eocene Latrobe Group, which hosts all the major oil and gas accumulations in the basin (Bernecker et al., 2003). It is characterised by a series of stacked cycles of siliciclastic sediments and coal measures that were deposited as the basin continued to evolve from a restricted rift to an open marine shelf, with the protracted opening of the Tasman Sea the primary tectonic control on sedimentation (Woollands and Wong, 2001; Power et al., 2003). It comprises four subgroups (Emperor, Golden Beach, Halibut and Cobia) that are bounded by basin-wide unconformities (Bernecker et al., 2003). Of particular relevance to this study are a series of Eocene unconformities that have been documented in detail by Holdgate et al. (2003a). The most significant of these is the Top Latrobe Unconformity. This angular (up to $5^{\circ}$ ), composite unconformity has locally removed $>20 \mathrm{Myr}$ of sedimentary section, and is characterised by significant topography that reflects substantial localised erosion (up to $600 \mathrm{~m}$ ) associated with incision of the Flounder and Marlin channels (Holdgate et al., 2003a). The age of the Top Latrobe unconformity is constrained to between 44 and 40 Ma based on the ages of the sediments that fill the incised channels, whilst an earlier unconformity (the Mackerel Unconformity) is dated at 53 to 51 Ma (Holdgate et al., 2003a).

The Top Latrobe Unconformity is overlain by the Seaspray Group offshore and the Latrobe Valley Group onshore (Holdgate and Gallagher, 2003). The Seaspray Group consists of cool-water carbonates that vary in thickness from $\sim 1 \mathrm{~km}$ near the basin margins and up to $\sim 3 \mathrm{~km}$ in the Central Deep (Holdgate and Gallagher, 2003), where it provides the overburden necessary for source rock maturation. Submarine canyon growth and infill is pervasive, especially in the Miocene section (Holdgate and Gallagher, 2003). The onshore Latrobe 
Valley Group consists of terrestrial siliciclastic sediments and coal measures that include some of Australia's largest brown coal accumulations (Holdgate, 2003). Reconstructions of Gippsland Basin sediment volumes demonstrate a marked increase in clastic sedimentation from the late Oligocene, culminating in a peak in the mid-Miocene (Bernecker and Partridge, 2001). The timing of this increase in clastic sedimentation is consistent with a 25 to 10 Ma cooling episode interpreted from AFTA data acquired from highly dissected river valleys in the southeastern highlands (Duddy, 2009). The top of the Seaspray Group and the Latrobe Valley Group is marked by a regional unconformity that occurs throughout the basins of southeastern Australia (Dickinson et al., 2002). Palynological and microfossil biostratigraphy combined with structural control constrain the age of the unconformity to latest Miocene or base Pliocene.

There is abundant evidence for a number of pulses of compressional deformation in the Gippsland Basin from the earliest mid-Eocene onwards. Most offshore compressional structures strike $\sim \mathrm{NE}-\mathrm{SW}$ to $\sim \mathrm{ENE}-\mathrm{WSW}$, whilst onshore structures mainly trend $\sim \mathrm{E}-\mathrm{W}$ to $\sim \mathrm{NNE}-$ SSW (Fig. 8) (Holdgate and Gallagher, 2003). The majority of these structures are anticlines and monoclines that have developed above $\sim$ E-W to $\sim$ NE-SW striking normal faults reactivated in compression (Holdgate et al., 2003a; Power et al., 2003). The basin experienced extensional deformation until the latest early Eocene, with growth faulting terminating just prior to the onset of compressional deformation and inversion in the Basin Deep and Northern Terrace $~ 52 \mathrm{Ma}$ (Johnstone et al., 2001). Offshore structures that initiated at this time include the Tuna and Flounder anticlines (Brown, 1986). This initial phase of compression was coincident with the erosion of the Flounder Channel and the development of the Mackerel Unconformity (Holdgate et al., 2003a). Apatite fission track samples collected from the Furneaux Islands located along the Bassian Rise to the south of the Gippsland Basin provide evidence for broadly coeval cooling and exhumation beginning between $\sim 65$ and $45 \mathrm{Ma}$ (O'Sullivan et al. 2000). A further, broad phase of offshore compression from the Oligocene to earliest Miocene is observed in northern and western parts of the basin during which large structures including Barracouta and Snapper began to develop (Johnstone et al., 2001). In contrast to the earlier $~ 52$ Ma deformation phase, Oligocene-early Miocene deformation was accompanied by little erosion, suggesting that most structures active at this time were below sea-level (Johnstone et al., 2001). Isolated compression in the mid-Miocene initiated the Kingfish Anticline and reactivation of structures such as Volador and Flounder (Johnstone et al., 2001). More widespread deformation from latest Miocene onwards, particularly focussed on the outer northern and western margins of the offshore basin reactivated and overprinted many structures, including Barracouta, Seahorse, Flying Fish (Fig. 14) and Turrum (Dickinson et al., 2001; Johnstone et al., 2001). Reactivation of the Rosedale Fault system initiated new structures such as Wahoo (Dickinson et al., 2001). Shallow offshore seismic reflection profiles from the inner central shelf of the basin show that deformation has continued into the Pleistocene on the basis of open folds observed in sediments of Lower Pliocene to Lower Pleistocene age (Mitchell et al., 2007).

Amongst the most conspicuous indications of post-breakup deformation and uplift in the onshore Gippsland Basin include the Strzelecki Ranges, a series of $\sim$ NE-SW-trending highlands (maximum elevation $\sim 750 \mathrm{~m} \mathrm{ASL}$ ) bound by $\sim \mathrm{NE}-\mathrm{SW}$ and $\sim$ E-W-trending faults, which mark the western basin margin (Sandiford, 2003a). The Strzelecki Ranges are analogous to the Otway Ranges in the Otway Basin in terms of their structural trend and the resistant Lower Cretaceous Strzelecki Group rocks that crop out across much of the highlands (Duddy, 2003). Oligocene-Miocene coal measures exhibit little or no stratigraphic thinning towards the Ranges and contain little evidence for siliciclastic input implying relatively low relief during these times (Dickinson et al., 2001). Webb et al. (2010) have attributed $\sim 600 \mathrm{~m}$ of the elevation of the $\sim 750 \mathrm{~m}$ high Strzelecki Ranges to uplift during the late Miocene to early Pliocene ( $\sim 8$ to 4 Ma). Pliocene and younger sediments that overlie the regional late Miocene-early Pliocene unconformity are generally undeformed (Dickinson et al., 2002). However, Holdgate et al. (2003b) have suggested that growth of the Baragwanath Anticline (Fig. 8), one of the largest onshore Gippsland Basin structures, continued into the mid-Pleistocene ( $\sim 0.5 \mathrm{Ma}$ or later) on the basis of its relations with eroded early to mid-Pleistocene river channels that cross the structure. Early-mid Pleistocene (1.5 to $0.25 \mathrm{Ma}$ ) displacement on the adjacent Rosedale Fault is estimated at between $\sim 60$ to $100 \mathrm{~m}\left(\sim 0.5\right.$ to $\left.0.8 \mathrm{~mm} \mathrm{yr}^{-1}\right)$ (Holdgate et al., 2003b). Marginally lower late Pliocene to late Pleistocene displacement rates $\left(\sim 0.5\right.$ to $\left.0.8 \mathrm{~mm} \mathrm{yr}^{-1}\right)$ have been estimated for the Waratah Fault, a $\sim \mathrm{NE}-\mathrm{SW}$-trending high angle reverse fault at Cape Liptrap, to the south of the Strzelecki and Hoddle Ranges (Gardner et al., 2009). Ongoing deformation is witnessed by the relatively high levels of seismicity within the basin, much of which is concentrated around the highlands along the western basin margin (Allen et al., 2005).

\section{REGIONAL SYNTHESIS}

The foregoing synthesis of structural, stratigraphic and thermochronological data demonstrates that the sedimentary basins of the southern Australian margin have witnessed recurrent, incremental compressional deformation (reverse faulting and resultant folding), uplift and exhumation since the mid-Eocene. This tectonic activity, though minor in comparison to that associated with active plate boundaries (where typical strain rates are $\sim 10^{-13}$ to $10^{-15} \mathrm{~s}^{-1}$ ), nonetheless runs counter to the general perception that the post-breakup evolution of passive continental margins is characterised by tectonic quiescence. Furthermore, this tectonic activity has exerted a fundamental control on the distribution of hydrocarbons in the Otway and Gippsland basins. Here we discuss the distribution and chronology of this post-breakup tectonic activity in relation to the dynamics of the Indo-Australian Plate since the mid-Eocene in an attempt to identify the primary controls on the deformation, uplift and exhumation of the southern Australian margin.

\section{Distribution and orientation of post-breakup compressional structures}

We first focus on the distribution and frequency of post-breakup compressional structures along the margin. The majority of these structures are anticlines or monoclines that formed within post-breakup or uppermost syn-breakup sediments because of reverse 
displacements on normal faults that formed during prior extensional events, though there is also evidence for the initiation of new reverse faults (Fig. 10). The density of compressional structures increases substantially from west to east along the margin, with relatively few structures in the Bight and Eucla basins, but substantially more in the Otway and Gippsland basins (Fig. 8). Within each basin, the orientations of structures are broadly consistent, irrespective of their age, but there is a clear rotation in the orientation of structures along the length of the margin. In the Eucla and St Vincent basins and their margins (e.g. the Mt Lofty Ranges), most post-breakup faults and folds trend broadly N-S to NNE-SSW (Figs. 4, 5). The dominant trend of compressional structures in the Otway Basin is $\sim$ NE-SW, which rotates to $\sim$ ENE-WSW to $\sim$ E-W in the offshore Gippsland Basin (Fig. 8).

\section{Origins of the stress field of the southern margin}

The orientations of post-breakup faults and folds are remarkably consistent with present-day maximum horizontal orientations determined from borehole breakouts and drilling induced tensile fractures observed in hydrocarbon exploration wells, and inferred from earthquake focal mechanisms (Clark and Leonard, 2003; Reynolds et al., 2005; Nelson et al., 2006; Hillis et al., 2008). No present-day stress data are available for western and central parts of the Bight and Eucla Basins, but six wells in the Duntroon sub-basin define a present-day maximum horizontal stress orientation of $130^{\circ} \mathrm{N}$ (Reynolds et al., 2005). Focal mechanisms for reverse and strike-slip earthquakes in the Flinders Ranges indicate a sub-horizontal maximum principal stress oriented at $082^{\circ} \mathrm{N}$. Available data therefore indicate that present-day maximum horizontal stress in central parts of the southern margin is oriented $\sim \mathrm{E}-\mathrm{W}$ to $\sim \mathrm{NW}$-SE, orthogonal to the strike of most post-breakup deformation structures. Present-day stress orientations are better constrained in the Otway and Gippsland basins, where data indicate $\sim \mathrm{NW}-\mathrm{SE}$ oriented maximum horizontal stress that rotates from $125^{\circ} \mathrm{N}$ in western parts of the Otway Basin to $139^{\circ} \mathrm{N}$ in the Gippsland Basin (Fig. 8) (Nelson et al., 2006). (We note that Nelson et al. (2006) report an accompanying increase in minimum horizontal stress from 15.5 MPa km${ }^{-1}$ in the western Otway Basin to $20 \mathrm{MPa} \mathrm{km}^{-1}$ in the Gippsland Basin). These stress orientations are again broadly orthogonal to the strikes of compressional structures in these basins (Hillis et al., 2008).

Valuable insights into the origin of the present-day stress field of the southern Australian margin have been provided by plate-scale finite element modelling studies (e.g. Reynolds et al., 2002, 2003; Sandiford et al., 2004). These studies have shown that present-day stress orientations and regimes across the Australian continent are largely a function of the net torques of all the plate boundary forces that drive and resist motion of the Indo-Australian plate (Reynolds et al., 2002). Key driving forces at the present-day include ridge-push (e.g. generated at Southern Ocean spreading system) and slab-pull (e.g. generated by the Sumatra-Java and Solomon-New Hebrides subduction systems), and resistance to plate motion is provided by continental collision (e.g. along the Himalayan, New Guinea and New Zealand segments of the plate boundary) (Reynolds et al., 2002). The overall consistency between the trends of post-breakup compressional structures and the palaeostress orientations they imply, and both observed and modelled present-day stress orientations (Fig. 15) strongly suggests that the ongoing deformation of the southern Australian margin is primarily controlled by plate boundary forces (Hillis et al., 2008). The notion that plate boundary forces have played a key role in controlling post-breakup deformation of the margin is supported by the clear correlations that exist between two major peaks in tectonic activity during the mid-Eocene and late Miocene to early-Pliocene, and important coeval reorganizations of the boundaries of the Indo-Australian plate.

\section{Early-to-mid Eocene deformation and plate tectonic setting}

The onset of the first broad phase of enhanced compressional activity during the early-mid Eocene is recorded by the $\sim 52 \mathrm{Ma}$ (Ypresian) Mackerel Unconformity in the Gippsland Basin and the contemporaneous development of inversion structures such as the Tuna and Flounder anticlines. Margin wide deformation and uplift beginning around $\sim 43 \mathrm{Ma}$ (Lutetian) is recorded by regional unconformities observed in the Otway, Torquay and Gippsland basins (Holdgate et al., 2003a; McGowran et al., 2004), and by inversion structures in the western Otway Basin that witness major localised exhumation constrained by AFTA data (e.g. Duddy et al., 2003) to beginning between 55 to $40 \mathrm{Ma}$ (Fig. 2). Prior to this, the tectonics of the southern margin was largely dominated by mild normal faulting associated with the final stages of southern margin breakup (e.g. Johnstone et al., 2001). However, during the early-mid Eocene several critical changes in plate configuration occurred which favoured the development of a compressional stress regime (Sandiford et al., 2004). The cessation of spreading in the Tasman Sea at $~ 52 \mathrm{Ma}$ (Gaina et al., 1998) was broadly coeval with the termination of spreading along the Wharton Basin Ridge in the north-central Indian Ocean to the northwest of Australia (Fig. 2) (Dyksterhuis and Müller, 2008). The latter event accompanied the deceleration of the Indian Plate during the initial stages of Himalayan collision, and was a key factor in the eventual fusion of the Indian and Australian plates (Sandiford and Quigley, 2009). Collision along the New Guinea passive margin around this time, accompanied by the emplacement of ophiolites northern New Guinea (Davies and Jaques, 1984), resulted in increased resisting forces to the north of Australia (Dyksterhuis and Müller, 2008).

We thus interpret the $\sim 52 \mathrm{Ma}$ inversion in the Gippsland Basin as recording the initial stages of a compressional tectonic regime along the southern Australian margin (cf. Dyksterhuis and Müller, 2008). A series of further critical plate boundary reconfigurations occurred at $\sim 43 \mathrm{Ma}$ (Veevers, 2000). The most important of these in terms of southern margin tectonics was the onset of fast spreading in the Southern Ocean (Norvick and Smith, 2001; McGowran et al., 2004). Geomagnetic anomalies south of the Bight Basin demonstrate that halfspreading rates increased markedly from 0.4 to $0.5 \mathrm{~cm} \mathrm{yr}^{-1}$ prior to $43 \mathrm{Ma}$, to $1.6 \mathrm{~cm} \mathrm{yr}^{-1}$ between 43 and $34 \mathrm{Ma}$, and $3.3 \mathrm{~cm} \mathrm{yr}^{-1} \mathrm{between}$ 34 and $30 \mathrm{Ma}$ (Fig. 2) (Li et al., 2003). Similar trends are observed to the west and south of Tasmania, although half-rates $>3 \mathrm{~cm} \mathrm{yr}^{-1}$ had been reached somewhat earlier (after $39 \mathrm{Ma}$ ) (Li et al., 2003). The acceleration in Southern Ocean spreading rates thus signals the 
increasing importance of ridge push in influencing the nascent compressional stress field of the southern margin, with the margin-wide $\sim 43$ Ma unconformity recording the combined effects of spatially variable inversion, uplift and exhumation, regional marine transgression (cf. McGowran et al., 2004), and in the case of the Eucla Basin, rapid subsidence which is recorded by the onlap of mid-late Eocene sediments onto underlying sequences (Totterdell et al., 2000).

\section{Late Miocene-Recent deformation and plate tectonic setting}

Deformation in the Otway to Gippsland basins continued intermittently throughout the Oligocene to early-mid Miocene, but a conspicuous increase in tectonic activity along the margin is apparent from the late Miocene onwards. This renewed phase of deformation was manifested by widespread fault reactivation and folding (locally associated with substantial cooling and exhumation), accelerated uplift of highlands (e.g. the Mt Lofty, Otway and Strzelecki Ranges) and the development of the late Miocene-early Pliocene unconformity observed in all basins east of Gulf St Vincent (Dickinson et al., 2001, 2002; Sandiford, 2003a; Sandiford et al., 2004). Dickinson et al. (2002) show that the time gap represented by the unconformity varies from $\sim 20$ to $5 \mathrm{Ma}$ in the eastern Otway Basin and Torquay sub-basin, where AFTA results indicate that coeval exhumation was the most severe (Fig. 8; Green et al., 2004; Holford et al. in press), to $\sim 10$ to $5 \mathrm{Ma}$ in the central Otway basin and Port Phillip Basin. This best estimate for the age of the unconformity compares well with independent constraints provided by AFTA and apatite (U-Th)/He data from the Anglesea-1 and Nerita-1 wells which indicate exhumation-driven cooling of preserved Miocene-Oligocene and older units beginning between 12 and $7 \mathrm{Ma}$, and 10 and 5 Ma, respectively (Green et al., 2004; Holford et al., 2010, in press).

The late Miocene-early Pliocene interval witnessed a number of significant changes in the nature of the boundaries of the IndoAustralian Plate that are likely to have profoundly influenced the stress field of the southern margin, and thus may account for the observed increase in deformation at this time (Hillis et al., 2008). One of the most consequential plate boundary reconfigurations was the formation of the Southern Alps in New Zealand between 12 and 6.4 Ma (Sandiford et al., 2004). Finite element modelling results indicate that the $\sim \mathrm{NW}$-SE maximum horizontal stress orientation in the basins of southeastern Australia to a large extent reflects their relative proximity to the New Zealand collision zone, and Sandiford et al. (2004) postulate that increased coupling of the Australian and Pacific plate boundary intensified stress magnitudes in eastern parts of the southern margin. This idea is supported to some extent by the observed increase in minimum horizontal stress magnitudes that occurs from the western Otway Basin to Gippsland Basin (Nelson et al., 2006).

A number of important modifications to the northern boundary of the Australian Plate occurred during the late Miocene-early Pliocene, including collision with the Banda Arc between 11-10 Ma (Keep and Haig, 2010), the onset of transpressional deformation and uplift throughout northern Papua New Guinea between $12-10$ Ma (Hill and Raza, 1999) and collision between the Ontong Java Plateau and the Solomon Arc beginning $\sim 6 \mathrm{Ma}$ (Wessel and Kroenke, 2000). The close correspondence between the timing of these events and the formation of the Southern Alps, with the regional increase in the intensity of deformation along the southern margin beginning in the late Miocene, provides important observational support for the finite element modelling results which suggest that intraplate stress regimes are highly sensitive to the nature and disposition of the surrounding plate boundary configurations (Reynolds et al., 2003; Sandiford et al., 2004).

Whilst we believe that many aspects of the $<45$ Ma deformation record of the southern Australian margin can be satisfactorily explained by the transmission of plate boundary forces into the plate interior, other features of the post-breakup tectonic record are less easily attributable to this general process. Most notable is the post-mid Miocene ( $\sim 15 \mathrm{Ma})$ record of several hundred metres of long-wavelength uplift preserved by the elevations of palaeo-shorelines (strandlines) from the Eucla Basin in the west to the Otway Basin in the east (Sandiford, 2007). Although the present-day elevation of strandlines in parts of the Otway Basin appear to have been influenced by both Quaternary volcanism (Sandiford et al., 2009) and the ongoing uplift of the Otway Ranges during the Pliocene (Sandiford, 2003b), the broader pattern of strandline elevations and Neogene offlap along the southern margin has been attributed to 250-300 m of N-down, SSWup tilting of the Australian continent with respect to sea level since the mid-Miocene (Sandiford, 2007). Sandiford (2007) has sought to explain this tilting as a consequence of the north-northeast motion of the Australian Plate over a complexly structured underlying mantle since the mid-Miocene. In his model, the long-wavelength uplift of the southern Australian margin since $\sim 15$ Ma can be understood in terms of its movement off a dynamic topography and geoid low that today is currently centred on the Australian-Antarctic Discordance in the Southern Ocean (Sandiford, 2007). Thus, whilst mantle structure and flow appears to exert a relatively subsidiary role in controlling the stress field of the Australian continent (e.g. Coblentz et al., 1995), the stratigraphic record of the southern margin suggests that mantle processes have made an important contribution to the late Neogene topographic evolution of the Australian continent.

\section{Controls on the localisation of deformation}

Much of this discussion has focussed on identifying and examining the 'external' factors related to plate and mantle dynamics that have ultimately driven the post-breakup deformation of the southern Australian margin, but it is also important to consider what 'internal' properties and factors have influenced the distribution and localisation of deformation. It is apparent that both the short-term (i.e. seismicity) and longer-term deformation along the margin appears to be localised into a number of discrete domains, suggesting that there are additional controls that govern the spatial distribution of fault initiation and reactivation (Hillis et al., 2008; Leonard, 2008; Sandiford and Egholm, 2008). For example, whereas the Otway and Gippsland basins in southeastern Australia are characterised by a relatively highdensity of post-breakup structures and high seismicity (Fig. 15), the Bight and Eucla basins contain far fewer faults (Fig. 15) and seismicity 
levels are amongst the lowest across the Australian continent (Leonard, 2008).

The absence of major Cenozoic inversion structures from the Bight Basin may imply that pre-existing faults in the basin have been unsuitably oriented for reactivation under the post-breakup stress fields. Mesozoic extension generated normal faults that predominantly strike ENE-WSW, E-W and ESE-WNW (Totterdell and Bradshaw, 2004). Reynolds et al. (2005) performed a fault-reactivation analysis for the Bight Basin, using the present-day stress constraints derived for the Duntroon sub-basin which indicate a maximum horizontal stress orientation of $\sim 130^{\circ} \mathrm{N}$ and a strike-slip or normal stress regime. Their results indicated that the only faults that have a high risk of reactivation under present-day stress conditions are those that strike ESE-WNW and dip steeply $\left(>70^{\circ}\right)$ if the dominant stress regime is strike-slip (Reynolds et al., 2005). Faults that strike ENE-WSW and E-W have very low reactivation potential, irrespective of their dip or the overall stress regime (Reynolds et al., 2005). It should be acknowledged that the $\sim \mathrm{NW}$-SE maximum horizontal stress orientation determined from wells in the Duntroon sub-basin may not be representative of stress orientations in western and central parts of the basin. The best-fitting finite element models of Reynolds et al. $(2002,2003)$ suggest that present-day maximum horizontal stress orientations along these parts of the southern margin are likely to trend $\sim \mathrm{E}-\mathrm{W}$, which is consistent with the NNW and NNE trends of fault scarps identified from digital elevation data from the onshore Eucla Basin (Hillis et al., 2008). These faults presumably initiated as 'Andersonian' reverse faults, striking approximately normal to the maximum horizontal stress orientation (cf. Anderson, 1951).

Another factor that might explain the relative lack of post-breakup compressional structures in the Bight and Eucla basins may relate to the thermal structure of the crust and lithosphere. It is well known that temperature is a critical control on the rheology of the crust and lithosphere, and several authors have argued that intraplate deformation should preferentially localise in regions of high heat flow, geothermal gradients or heat production (e.g. Kusznir and Park, 1982). Célérier et al. (2005) have argued that the enhanced seismicity of the Flinders Ranges in South Australia may be associated with high concentrations of heat producing elements in the crust (as reflected by high heat flows and heat production rates), which have led to rheological weakening and thereby localised deformation. Both onshore (e.g. Cull, 1982) and offshore (e.g. Goutorbe et al., 2008) maps of Australian surface heat flow show clear increases in values from west to east along the southern Australian margin. Available data from the Bight and Eucla basins indicating relatively low heat flows (mostly $<40-50$ $\mathrm{mWm}^{-2}$ ) in comparison to the Otway and Gippsland basins (mostly $>60-70 \mathrm{mWm}^{-2}$ ). The relative lack of post-breakup deformation structures along western and central parts of the margin might therefore imply that the underlying lithosphere is colder and stronger, and therefore less prone to deformation (Fig. 15).

\section{CONCLUSIONS}

A synthesis of structural, stratigraphic and thermochronological data from the southern Australian margin reveals that this passive continental margin has been subject to near-continual post-breakup compressional deformation since the early Eocene, and has witnessed recurrent phases of uplift and exhumation. Major peaks in tectonic activity occurred during the early-mid Eocene and late Miocene-early Pliocene, and are marked by regional, often angular unconformities that can be correlated across many of the individual depocentres located along the margin. These periods of enhanced tectonic activity show close temporal correspondence with major reconfigurations of the boundaries of the Indo-Australian Plate, whilst the palaeostress orientations inferred from neotectonic faults and folds are highly consistent with independent determinations of present-day maximum horizontal stress orientations (Hillis et al., 2008). Plate-scale stress modelling that explicitly accounts for the heterogeneous boundaries of the Indo-Australian Plate indicates that present-day stress orientations across the Australian continent are consistent with a first-order control by plate-boundary forces (Reynolds et al., 2002). We therefore infer that stresses transmitted from plate boundaries into the plate interior have exerted the dominant control on post-breakup deformation along the southern Australian margin. Post-breakup structures are not distributed uniformly along the margin, as the density of reverse faults and anticlines is much lower in the Bight and Eucla basin than along southeastern parts of the margin. We interpret the absence of major inversion structures from the Bight Basin as reflecting the unsuitable orientation of faults for reactivation with respect to post-breakup stress fields, and the colder, stronger lithosphere that underlies that part of the margin. Our observations suggest that the preserved sedimentary successions at passive continental margins can act as sensitive recorders of evolving plate boundary configurations and the forces they generate.

Post-breakup deformation, uplift and exhumation has exerted a major control on the hydrocarbon endowment of the southern Australian margin. Many of the largest oil and gas fields in the Otway and Gippsland basins are located in structural traps that formed during sedimentary basin inversion. It is important to recognise that many of the largest hydrocarbon-bearing structures in the petroliferous sedimentary basins of central Australia and the North West Shelf also formed as a direct result of post-early Eocene compression (e.g. Etheridge et al., 1991). Establishing precise deformation chronologies for these regions in relation to the results presented here will improve our understanding of the evolution of stress fields across the Australian continent throughout the Cenozoic, and may also provide valuable insights into the likely timing of trap formation along Australia's relatively unexplored southwestern and eastern frontier margins.

\section{ACKNOWLEDGMENTS}

This work forms part of ARC Discovery Project DP0879612 and represents TRaX contribution \#131. We thank Will Jones, Adam Smith, Iain Brown and Huw Edwards of PGS for provision of SAMDA, and gratefully acknowledge Geoscience Australia, PIRSA and DPI Victoria for access to seismic and well data. We thank Steve Mackie for editorial assistance and Jennie Totterdell for a helpful review. The 
contribution of Stoker is made with the permission of the Director of the British Geological Survey (Natural Environment Research Council).

\section{REFERENCES}

ALLEN, T.I., GIBSON, G. AND CULL, J.P. 2005-Stress-field constraints from recent intraplate seismicity in southeastern Australia. Australian Journal of Earth Sciences, 52, 217-230.

ALLEY, N. F. AND LINDSAY, J. M. 1995-Tertiary. In: Drexel J. F. and Preiss W. V. (eds) The Geology of South Australia, Vol. 2, The Phanerozoic. Geological Survey of South Australia Bulletin 54, 151-215.

ANDERSON, E.M. 1951-The Dynamics of Faulting and Dyke Formation with Application to Britain. $2^{\text {nd }}$ edition. Oliver and Boyd, Edinburgh.

BACKÉ, G., KING, R.K., HOLFORD, S.P. \& ABUL KHAIR. H. 2011-Fracture mapping and modelling in shale-gas targets in the Cooper and Otway basins, South Australia. The APPEA Journal, 51.

BERNECKER, T. AND PARTRIDGE, A.D. 2001-Emperor and Golden Beach Subgroups: The onset of Late Cretaceous Sedimentation in the Gippsland Basin, SE Australia. In: Hill, K.C. and Bernecker, T. (eds) Eastern Australasian Basins Symposium, A Refocused Energy Perspective for the Future, Petroleum Exploration Society of Australia, Special Publication, 391-402.

BERNECKER, T., SMITH, M.A., HILL, K.A. AND CONSTANTINE, A.E. 2003-Oil and gas, fuelling Victoria's economy. In: Birch, W.D. (ed) Geology of Victoria, GSA Special Publication 23, 469-487.

BLEVIN, J. (compiler), 2003-Petroleum geology of the Bass Basin: interpretation report. An output of the Western Tasmanian Regional Minerals Program. Geoscience Australia Record 2003/19.

BLEVIN, J. AND CATHRO, D. 2008-Australian Southern Margin Synthesis. Project GA707, Client report to Geoscience Australia by FrOG Tech Pty Ltd.

BLEVIN, J.E., TRIGG, K.R., PARTRIDGE, A.D., BOREHAM, C.J. AND LANG, S.C. 2005-Tectonostratigraphy and potential source rocks of the Bass Basin. The APPEA Journal, 45, 601-621.

BOND, G.C., AND KOMINZ, M.A. 1988-Evolution of thought on passive continental margins from the origin of geosynclinal theory $(\sim 1860)$ to the present. Geological Society of America Bulletin, 100, 1903-1933.

BOULT, P.J. AND HIBBURT, J.E. (Eds) 2002-The petroleum geology of South Australia. Volume 1: Otway Basin, South Australia. Department of Primary Industries and Resources. Petroleum Geology of South Australia Series 1, 2nd edition.

BRADSHAW, B.E., ROLLET, N., TOTTERDELL, J.M. AND BORISSOVA, I. 2003-A revised structural framework for frontier basins on the southern and southwestern Australian continental margin. Geoscience Australia, Record 2003/03.

BROWN, B.R. 1986-Offshore Gippsland Silver Jubilee. In: Glenie, R.C. (ed) Second South-Eastern Australia Oil Exploration Symposium, Melbourne The Petroleum Exploration Society of Australia Victoria and Tasmanian Branch, Canberra, Australia, 29-56.

CÉLÉRIER, J., SANDIFORD, M., HANSEN, D.L. AND QUIGLEY, M., 2005-Modes of active intraplate deformation, Flinders ranges, Australia. Tectonics, 24 (6), 10.1029/2004TC001679.

CLARK, D. AND LEONARD, M., 2003-Principal stress orientations from multiple focal-plane solutions: new insight into the Australian intraplate stress field. In: Hillis, R.R. and Muller, R.D. (eds) Evolution and Dynamics of the Australian Plate, GSAm Special Publication 22 and GSA Special Paper 372,91-105.

COBBOLD, P.R., MEISLING, K.E., AND MOUNT, V.S. 2001-Reactivation of an obliquely rifted margin, Campos and Santos basins, southeastern Brazil: AAPG Bulletin, 85, 1925-1944.

COBLENTZ, D.D., SANDIFORD, M., RICHARDSON, R.M., ZHOU, S. AND HILLIS, R.R. 1995-The origins of the intraplate stress field in continental Australia. Earth and Planetary Science Letters, 133, 299-309.

COOK, P.J. 2009-Demonstration and deployment of carbon dioxide capture and storage in Australia. Energy Procedia, 1, $3859-3866$. 
COOPER G. T. AND HILL K. C. 1997-Cross-section balancing and thermochronological analysis of the Mesozoic development of the eastern Otway Basin. The APPEA Journal, 37, 390-414.

CULL, J.P. 1982-An appraisal of Australian heat-flow data. BMR Journal of Australian Geology and Geophysics, 7, 11-21.

CUMMINGS, A.M., HILLIS, R.R. AND TINGATE, P.R. 2004-New perspectives on the structural evolution of the Bass Basin; implications for petroleum prospectivity. In: Boult, P.J., Johns, D.R. and Lang, S.C. (eds) Eastern Australian basins symposium II, PESA Special Publication, 133-149.

DAVIES, H.L. AND JAQUES, A.L. 1984-Emplacement of ophiolites in Papua New Guinea. In: Gass, I.G., Lippard, S.J. and Shelton, A.W. (eds) Ophiolites and Oceanic Lithosphere, GSL, Special Publication 14, 341-349.

DICKINSON, J.A., WALlACE, M.W., HOLDGATE, G.R., DANIELS, J., GALlAGHER, S.J. AND THOMAS, L. 2001-Neogene tectonics in SE Australia: implications for petroleum systems. The APPEA Journal, 41, 37-52.

DICKINSON, J.A., WALlACE, M.W., HOLDGATE, G.R., GALLAGHER, S.J. AND THOMAS, L., 2002-Origin and timing of the Miocene-Pliocene unconformity in southeast Australia. Journal of Sedimentary Research, 72 (2), 288-303.

DORÉ, A.G., LUNDIN, E.R., KUSZNIR, N.J. AND PASCAL, C. 2008-Potential mechanisms for the genesis of Cenozoic domal structures on the NE Atlantic margin: pros, cons, and some new ideas. In: Johnson, H., Doré, A.G., Gatliff, R.W., Holdsworth, R., Lundin, E.R. and Ritchie, J.D. (eds) The nature and origin of compression in passive margins, GSL, Special Publication 306, 1-26, $10.1144 /$ SP306.1.

DUDDY, I. R. 1994-The Otway Basin: thermal, structural and tectonic and hydrocarbon generation histories. In: Finlayson D. M. (ed) Extended abstracts, NGMA/PESA Otway Basin Symposium, Melbourne, 20 April 1994. Record of the Australian Geological Survey Organisation 1999/14, 35-42.

DUDDY, I.R. 1997-Focussing exploration in the Otway Basin: understanding timing of source rock maturation. The APPEA Journal, 37 , 178-191.

DUDDY, I.R. 2003-Mesozoic, a time of change in tectonic regime. In: Birch, W.D. (ed) Geology of Victoria, GSA Special Publication 23, 239-286.

DUDDY, I. R. 2009-Origin of the Australian Highlands. In: Norvick M. S. and Gallagher S. J. (eds) Origin of the Australian Highlands, Selwyn Symposium of the GSA Victoria Division, September 2009. Geological Society of Australia Extended Abstracts 94, 71-78.

DUDDY, I.R. AND EROUT, B. 2001-AFTA ${ }^{\circledR}$-calibrated 2-D modelling of hydrocarbon generation and migration using Temispack ${ }^{\circledR}$ preliminary results from the Otway Basin. In: Hill, K.C. and Bernecker, T. (eds) Eastern Australian Basins Symposium, A refocussed energy perspective for the future, PESA, Special Publication, 485-497.

DUDDY, I.R, EROUT, B., GREEN, P.F., CROWHURST, P.V. AND BOULT, P.J. 2003-Timing constraints on the structural history of the western Otway Basin and implications for hydrocarbon prospectivity around the Morum High, South Australia. The APPEA Journal, $43,59-83$.

DYKSTERHUIS, S. AND MÜLLER, R.D. 2008-Cause and evolution of intraplate orogeny in Australia. Geology, 36, 495-498, doi:10.1130/G24536A.1.

ETHERIDGE, M., MCQUEEN, H. AND LAMBECK, K. 1991-The role of intraplate stress in Tertiary (and Mesozoic) deformation of the Australian continent and its margins: a key factor in petroleum trap formation. Exploration Geophysics, 22, 123-128.

FEARY, D.A., HINE, A.C. AND MALONE, M.J. 2000-Proceedings of the Ocean Drilling Program, Initial Report 182. Ocean Drilling Program, College Station, Texas.

FLÖTTMANN, T. AND COCKSHELL, C.D. 1996-Palaeozoic basins of southern South Australia: new insight into their structural history from regional seismic data, Australian Journal of Earth Sciences, 43, 45-55.

GAINA, C., MÜLLER, D.R., ROYER, J-Y., STOCK, J., HARDEBECK, J., AND SYMONDS, P. 1998-The tectonic history of the Tasman Sea: A puzzle with 13 pieces. Journal of Geophysical Research, 103, 12413-12433.

GARDNER, T., WEBB, J., PEZZIA, C., AMBORN, T., TUNNELL, R., FlANAGAN, S., MERRITTS, D., MARSHALL, J., FABEL, D. AND CUPPER, M.L. 2009-Episodic intraplate deformation of stable continental margins: evidence from Late Neogene and Quaternary marine terraces, Cape Liptrap, Southeastern Australia. Quaternary Science Reviews, 28, 39-53. 
GEOSCIENCE AUSTRALIA AND ABARE. 2010-Australian Energy Resource Assessment, Canberra.]

GOUTORBE, B., LUCAZEAU, F. AND BONNEVILLE, A. 2008-Surface heat flow and the mantle contribution on the margins of Australia: Geochemistry, Geophysics, Geosystems, 9, Q05011, doi:10.1029/2007GC001924.

GREEN, P.F., CROWHURST, P.V. AND DUDDY, I.R. 2004-Integration of AFTA and (U-Th)/He thermochronology to enhance the resolution and precision of thermal history reconstruction in the Anglesea-1 well, Otway Basin, SE Australia. In: Boult, P.J., Johns, D.R. and Lang, S.C. (eds) Eastern Australian basins symposium II, PESA Special Publication, 117-131.

GREENHALGH, S.A., LOVE, D., MALPAS, K. AND MCDOUGALL, R. 1994-South Australian seismicity, 1980-1990. Australian Journal of Earth Sciences, 41, 483-495.

HILL, K. C. AND RAZA, A. 1999-Arc-continent collision in Papua New Guinea: Constraints from fission track thermochronology. Tectonics, 18, 950-966.

HILL, K.C., HILL, K.A., COOPER, G.T., O’SUlLIVAN, A.J., O’SUlliVAN, P.B. AND RICHARDSON, M.J. 1995-Inversion around the Bass Basin, SE Australia. In: Buchanan, J.G. and Buchanan, P.G. (eds) Basin Inversion, GSL, Special Publication 88, 525-547.

HILLIS, R.R., SANDIFORD, M., REYNOLDS, S.D. AND QUIGLEY, M.C. 2008-Present-day stress, seismicity and Neogene-to-Recent tectonics of Australia's 'passive' margins: intraplate deformation controlled by plate boundary forces. In: Johnson, H., Doré, A.G., Gatliff, R.W., Holdsworth, R., Lundin, E.R. and Ritchie, J.D. (eds) The nature and origin of compression in passive margins, GSL, Special Publication 306, 71-90, 10.1144/SP306.3.

HOLDGATE, G.R. 2003-Coal, world-class energy reserves without limits. In: Birch, W.D. (ed) Geology of Victoria, GSA Special Publication 23, 489-516.

HOLDGATE, G. R. AND GALLAGHER, S. J. 2003-Tertiary, a period of transition to marine basin environments. In: Birch, W.D. (ed) Geology of Victoria, GSA Special Publication 23, 289-335.

HOLDGATE, G.R., SMITH, T.A.G., GALLAGHER, S.J. AND WALLACE, M.W. 2001-Geology of coal-bearing Palaeogene sediments, onshore Torquay Basin, Victoria. Australian Journal of Earth Sciences, 48, 657-679.

HOLDGATE, G.R., RODRIQUEZ, C., JOHNSTONE, E.M., WALLACE, M.W. AND GALLAGHER, S.J. 2003a-The Gippsland Basin Top Latrobe Unconformity, and its expression in other SE Australian basins. The APPEA Journal, 43, 149-173.

HOLDGATE, G.R., WALlACE, M.W., GALLAGHER, S.J., SMITH, A.J., KEENE, J.B., MOORE, D. AND SHAKIF, S. 2003b-PlioPleistocene tectonics and eustasy in the Gippsland Basin, southeastern Australia: evidence from magnetic imagery and marine geological data. Australian Journal of Earth Sciences, 50, 37-52.

HOLDGATE, G.R., WALlACE, M.W., GALLAGHER, S.J., WAGSTAFF, B.E. AND MOORE, D. 2008-No mountains to snow on: major post-Eocene uplift of the East Victoria highlands; evidence from Cenozoic deposits. Australian Journal of Earth Sciences, 55, 211$234,10.1080 / 08120090701689373$.

HOLFORD, S.P., GREEN, P.F., DUDDY, I.R., TURNER, J.P., HILLIS, R.R. AND STOKER, M.S. 2009a-Regional intraplate exhumation episodes related to plate boundary deformation. GSA Bulletin, 121 (11-12), 1611-1628, 10.1130/B26481.

HOLFORD S.P., TURNER J.P., GREEN P.F. AND HILLIS R.R. 2009b-Signature of cryptic sedimentary basin inversion revealed by shale compaction data in the Irish Sea, western British Isles. Tectonics, 28, TC4011, doi:10.1029/2008TC002359.

HOLFORD, S.P., HILLIS, R.R., DUDDY, I.R., GREEN, P.F., TUITT, A.K. AND STOKER, M.S. 2010-Impacts of Neogene-Recent compressional deformation and uplift on hydrocarbon prospectivity of the passive southern Australian margin. The APPEA Journal, 50, 267-285.

HOLFORD, S.P., HILLIS, R.R., DUDDY, I.R., GREEN, P.F., TASSONE, D.R. AND STOKER, M.S. In press-Palaeothermal and seismic constraints on late Miocene-Pliocene uplift and deformation on the Torquay sub-basin, southern Australian margin. Australian Journal of Earth Sciences.

HOU, B., ALLEY, N.F., FRAKES, L.A., STOIAN, L. AND COWLEY, W.M. 2006-Eocene stratigraphic succession in the Eucla Basin of South Australia and correlation to major regional sea-level events. Sedimentary Geology, 183, 297-319. 
HOU, B., FRAKES, L.A., SANDIFORD, M., WORALL, L., KEELING, J. AND ALLEY, N.F. 2008-Cenozoic Eucla Basin and associated palaeovalleys, southern Australia - Climatic and tectonic influences on landscape evolution, sedimentation and heavy mineral accumulation. Sedimentary Geology, 203, 112-130.

HUDEC, M.R., AND JACKSON, M.P.A. 2002-Structural segmentation, inversion and salt tectonics on a passive margin: Evolution of the Inner Kwanza Basin, Angola. Geological Society of America Bulletin, 114, 1222-1244.

JAMES, N.P., BONE, Y., CARTER, R.M. AND MURRAY-WALLACE, C.V. 2006-Origin of the Late Neogene Roe Plains and their calcarenite veneer: Implications for sedimentology and tectonics in the Great Australian Bight. Australian Journal of Earth Sciences, 53, 407-419.

JOHNSTONE, E.M., JENKINS, C.C. AND MOORE, M.A. 2001-An integrated structural and palaeogeographic investigation of Eocene erosional events and related hydrocarbon potential in the Gippsland Basin. In: Hill, K.C. and Bernecker, T. (eds), Eastern Australasian Basins Symposium, A Refocused Energy Perspective for the Future, Petroleum Exploration Society of Australia, Special Publication, 403412.

KEEP, M. AND HAIG, D.W. 2010-Deformation and exhumation in Timor: distinct stages of a young orogeny. Tectonophysics, 483, 93111, doi:10.1016/j.tecto.2009.11.018.

KRASSAY, A.A., CATHRO, D.L. AND RYAN, D.J. 2004-A regional tectonostratigraphic framework for the Otway Basin. In: Boult, P.J., Johns, D.R. and Lang, S.C. (eds) Eastern Australian basins symposium II, PESA Special Publication, 97-106.

KUSZNIR, N.J. AND PARK, R.G. 1982-Intraplate lithosphere strength and heat flow. Nature, 299, 540-542.

LENNON, R.G., SUTTILL, R.J., GUTHRIE, D.A. AND WALDRON, A.R. 1999-The renewed search for oil and gas in the Bass Basin: results of Yolla-2 and White Ibis-1. The APPEA Journal, 39, 248-262.

LEONARD, M. 2008-One hundred years of earthquake recording in Australia. Bulletin of the Seismological Society of America, 98, 1458$1470,10.1785 / 0120050193$.

LI, Q., JAMES, N. P. AND MCGOWRAN, B. 2003-Middle and Late Eocene Great Australian Bight lithobiostratigraphy and stepwise evolution of the southern Australian continental margin. Australian Journal of Earth Sciences, 50, 113-128.

LI, Q., SIMO, J.A., MCGOWRAN, B. AND HOLBOURN, A. 2004-The eustatic and tectonic origin of Neogene unconformities from the Great Australian Bight. Marine Geology, 203, 57-81.

LISTER, G.S., ETHERIDGE, M.A. AND SYMONDS, P.A. 1991--Detachment models for the formation of passive continental margins. Tectonics, 10, 1038-1064.

MCGOWRAN, B., HOLDGATE, G. R., LI, Q. AND GALLAGHER, S. J. 2004-Cenozoic stratigraphic succession in southeastern Australia. Australian Journal of Earth Sciences, 51, 459-496.

MACDONALD, J.D., KING, R.C., HILLIS, R.R. AND BACKÉ, G. 2010-Structural style of the White Pointer and Hammerhead deltadeepwater fold-thrust belts, Bight Basin, Australia. The APPEA Journal, 50, 487-510.

MESSENT, B.E., COLLINS, G.I. AND WEST, B.G. 1999-Hydrocarbon prospectivity of the offshore Torquay sub-basin, Victoria: gazettal area V99-1, Victoria Initiative for Minerals and Petroleum 60.

MITCHELL, J.K., HOLDGATE, G.R., AND WALLACE, M.W. 2007-Pliocene-Pleistocene history of the Gippsland Basin outer shelf and canyon heads, southeast Australia. Australian Journal of Earth Sciences, 54, 49-64.

NELSON, E.J., HILLIS, R.R., SANDIFORD, M., REYNOLDS, S.D. AND MILDREN, S.D. 2006-Present-day state-of-stress of southeast Australia. The APPEA Journal, 46, 283-305.

NORVICK, M.S. AND SMITH, M.A. 2001-Mapping the plate tectonic reconstruction of southern and southeastern Australia and implications for petroleum systems. The APPEA Journal, 41, 15-35.

O'SULLIVAN, P.B., MITCHELL, M.M., O'SULLIVAN, A.J., KOHN, B.P. AND GLEADOW, A.J.W. 2000-Thermotectonic history of the Bassian Rise, Australia: implications for the breakup of eastern Gondwana along Australia's southeastern margins. Earth and Planetary Science Letters, 182, 31-47. 
PERINCEK, D. AND COCKSHELL, C.D. 1995-The Otway Basin: Early Cretaceous rifting to Neogene inversion. The APEA Journal, 35 , $451-466$

POWER, M.R., HILL, K.C. AND HOFFMAN, N. 2003-Structural inheritance, stress rotation and compressional reactivation in the Gippsland Basin-Tuna 3D seismic data set. The APPEA Journal, 43, Pt 1, 197-221.

PRAEG, D., STOKER, M.S., SHANON, P.M., CERAMICOLA, S., HJELSTUN, B.O. AND MATHIESEN, A. 2005-Episodic Cenozoic tectonism and the development of the NW European 'passive' continental margin. Marine and Petroleum Geology, 22, $1007-1030$.

QUIGLEY, M., CUPPER, M. AND SANDIFORD, M., 2006-Quaternary faults of southern Australia: palaeoseismicity, slip rates and origin. Australian Journal of Earth Sciences, 53, 285-301

REYNOLDS, S.D., COBLENTZ, D.D. AND HILLIS, R.R., 2002-Tectonic forces controlling the regional intraplate stress field in continental Australia: results from new finite-element modelling. Journal of Geophysical Research, 107 (B7), 10.1029/2001JB000408.

REYNOLDS, S. D., COBLENTZ, D. D. \& HILLIS, R. R. 2003-Influences of plate-boundary forces on the regional intraplate stress field of continental Australia. In: Hillis, R.R. and Muller, R.D. (eds) Evolution and dynamics of the Australian plate, GSA Special Publication 22 and GSAm Special Paper 372, 59-70.

REYNOLDS, S.D., PARASCHIVOIU, E., HILLIS, R.R. AND O'BRIEN G.W. 2005-A regional analysis of fault reactivation and seal integrity using the FAST technique: An example from the Bight Basin, Australia. In: Boult, P. and Kaldi, J. (eds) Evaluating Fault and Caprock Seals, AAPG Hedberg Series 2, 57-71.

ROYER, J-Y. AND ROLLET, N. 1997-Plate Tectonic setting of the Tasmanian Region. Australian Journal of Earth Sciences, 44, 543-560.

SANDIFORD, M. 2003a-Neotectonics of southeastern Australia: linking the Quaternary faulting record with seismicity and in situ stress. In: Hillis, R.R. and Muller, R.D. (eds) Evolution and dynamics of the Australian plate, GSA Special Publication 22 and GSAm Special Paper 372, 107-19.

SANDIFORD, M. 2003b-Geomorphic constraints on the late Neogene tectonics of the Otway Range. Australian Journal of Earth Sciences, $50,69-80$.

SANDIFORD, M. 2007-The tilting continent: A new constrain on the dynamic topographic field from Australia. Earth and Planetary Science Letters, 261, 152-163, 10.1016/j.eps1.2007.06.023.

SANDIFORD, M. AND EGHOLM, D.L. 2008-Enhanced intraplate seismicity across continental margins: some causes and consequences. Tectonophysics, 457, 197-208, doi:10.1016/j.tecto.2008.06.004.

SANDIFORD, M. AND QUIGLEY, M. 2009-TOPO-OZ: Insights into the various modes of intraplate deformation in the Australian continent. Tectonophysics, 474, 405-416, 10.1016/j.tecto.2009.01.028.

SANDIFORD, M., WALLACE, M. AND COBLENTZ, D. 2004-Origin of the in situ stress field in southeastern Australia. Basin Research, 16, 325-38.

SANDIFORD, M., QUIGLEY, M., DE BROKERT, P. AND JAKICA, S. 2009-Tectonic framework for the Cenozoic cratonic basins of Australia. Australian Journal of Earth Sciences, 56, S5-S18.

SAYERS, J., SYMONDS, P.A., DIREEN, N.O. AND BERNARDEL, G. 2001- Nature of continent-ocean transition on the non volcanic rifted margin of the central Great Australian Bight. In: Wilson R.C.L., Whitmarsh, R.B., Taylor, B. and Froitzheim, N. (eds) Non-volcanic rifting of oceanic margins: a comparison of evidence from land and sea, GSL, Special Publication 187, 51-76.

SCHNEIDER, C.L., HILL, K.C. AND HOFFMAN, N., 2004-Compressional growth of the Minerva Anticline, Otway Basin, Southeast Australia-evidence of oblique rifting. The APPEA Journal, 44 (1), 463-80.

SCHOFIELD, A. AND TOTTERDELL, J.M. 2008-Distribution, timing and origin of magmatism in the Bight and Eucla Basins. Geoscience Australia, Record 2008/24.

STOKER, M.S., HOULT, R.J., NIELSEN, T., HJELSTUN, B.O., LABERG, J.S., SHANNON, P.M., PRAEG, D., MATHIESEN, A., VAN WEERING, T.C.E. AND McDONNELL, A. 2005-Sedimentary and oceanographic responses to early Neogene compression on the NW European margin. Marine and Petroleum Geology, 22, 1031-1044. 
TASSONE, D.R., HOLFORD, S.P. AND HILLIS, R.R. 2010-Quantification of Cretaceous-Cenozoic exhumation in the Otway Basin using sonic velocities and implications for hydrocarbon exploration. ASEG 2010, Sydney, 1-4.

TICKELL, S.J., EDWARDS, J. AND ABELE, C. 1992-Port Campbell Embayment 1:100 000 map, geological report. Geological Survey of Victoria Report 95.

TIKKU, A.A. AND CANDE, S.C. 1999-The oldest magnetic anomalies in the Australian-Antarctic Basin: Are they isochrons? Journal of Geophysical Research, 104 (B1), 661-677.

TOTTERDELL, J.M. AND BRADSHAW, B.E. 2004-The structural framework and tectonic evolution of the Bight Basin. In: Boult, P.J., Johns, D.R. and Lang, S.C. (eds) Eastern Australian basins symposium II, PESA Special Publication, 41-61.

TOTTERDELL, J.M. AND KRASSAY, A.A., 2003-The role of shale deformation and growth faulting in the Late Cretaceous evolution of the Bight Basin, offshore southern Australia. In: Van Rensbergen, P., Hillis, R.R., Maltman, A.J. and Morley, C.K. (eds), Subsurface sediment mobilisation. Geological Society of London, Special Publications, 216, 429-442.

TOTTERDELL, J.M., BLEVIN, J.E., STRUCKMEYER, H.I.M., BRADSHAW, B.E., COLWELL, J.B. AND KENNARD, J.M., 2000-A new sequence framework for the Great Australian Bight: starting with a clean slate. APPEA Journal, 40, 95-117.

TRUPP, M.A., SPENCE, K.W. AND GIDDING, M.J. 1994-Hydrocarbon prospectivity of the Torquay Sub-Basin, Offshore Victoria. APEA Journal, 34, 479-494.

TUITT, A.K., HOLFORD, S.P., HILLIS, R.R., UNDERHILL, J.R., RITCHIE, J.D., JOHNSON, H., HITCHEN, K., STOKER, M.S. AND TASSONE, D.R. 2011-Continental margin compression: a comparison between compression in the Otway Basin of the southern Australian margin and the Rockall-Faroe area in the NE Atlantic margin. The APPEA Journal, 51.

TURNER, J.P., GREEN, P.F., HOLFORD, S.P. AND LAWRENCE, S.R. 2008-Thermal history of the Rio Muni (West Africa)-NE Brazil margins during continental breakup. Earth and Planetary Science Letters, 270, 354-367.

VEEVERS, J.J. 2000-Change of tectono-stratigraphic regime in the Australian plate during the 99 Ma (mid-Cretaceous) and 43 Ma (midEocene) swerves of the Pacific. Geology, 28, 47-50.

WALLACE, M.W., DICKINSON, J.A., MOORE, D.H. and SANDIFORD, M. 2005-Late Neogene strandlines of southern Victoria: a unique record of eustasy and tectonics in southeast Australia. Australian Journal of Earth Sciences, 52, 277-295.

WEBB, J.A., GARDNER, T.W., KAPOSTASTY, D., BREMAR, K.A. AND FABEL, D. 2010-Mountain building along a passive margin: Late Neogene tectonism in southeastern Victoria, Australia. Geomorphology, doi:12.1016/j.geomorph.2010.09.022.

WESSEL, P. AND KROENKE, L.W. 2000-Ontong Java Plateau and late Neogene changes in Pacific plate motion. Journal of Geophysical Research, 105(B12), 28255-28277, doi:10.1029/2000JB900290.

WHITE, N., THOMPSON, M. AND BARWISE, T. 2003-Understanding the thermal evolution of deep-water continental margins. Nature, 426, 334-343.

WILLIAMS G. D., POWELL C. M. AND COOPER M. A. 1989-Geometry and kinematics of inversion tectonics. In: Cooper, M.A. and Williams, G.D. (eds) Inversion Tectonics, GSL, Special Publication 44, 3-15.

WOOLLANDS, M.A. AND WONG, D. 2001-Petroleum Atlas of Victoria, Australia. The State of Victoria, Department of Natural Resources and Environment.

\section{Figure Captions}

Figure I. Southern Australian margin location map showing main basins considered in this study. Seismicity based on Geoscience Australia's 1900-2007 earthquake database, faults with evidence for post-breakup displacement compiled from Sandiford (2003), Hillis et al. (2008) and Holdgate et al. (2008), and approximate position of I5 Ma shoreline modified after Veevers (2000).

Figure 2. Southern Australian margin tectonostratigraphic event chart, highlighting key correlations between mid and late-Cenozoic cooling episodes constrained by unpublished Geotrack AFTA data with regional unconformities and margin-wide deformation pulses. Stratigraphy modified from Blevin and Cathro (2008), relevant southern and northern Australian margin tectonic events adapted from Li 
et al. (2004), and 100, 55, 25-23 and 6-0 Ma plate reconstructions modified from Dyksterhuis and Muller (2008).

Figure 3. Part of seismic line from the northern Ceduna sub-basin (modified after Totterdell et al. 2000). Note evidence for normal faulting within the Cretaceous succession, with faults tipping out at the base of the Cenozoic succession, which is marked by a regional, low-angle unconformity. The thin post-mid-Eocene succession is planar and undeformed. See Fig. I for location. Seismic data provided by PGS (SAMDA).

Figure 4. Digital elevation image of the Nullarbor Plain, indicating positions of 15, 4 and 0 Ma shorelines (modified after James et al., 2006; Sandiford, 2007), and the presence of $\sim \mathrm{N}-\mathrm{S}$ trending faults with maximum fault scarp height measurements of $\sim 15$ and $20 \mathrm{~m}$ (Hillis et al., 2008). Black arrows indicated inferred regional maximum horizontal stress orientation.

Figure 5. St Vincent Basin location map, showing extent of Cenozoic sediments and faults with evidence for post-breakup displacement (modified after Alley and Lindsay, 1995). Note that extent of Cenozoic sediments in the Murray, Pirie and numerous sub-basins is not shown. Note that the emergent Yorke and Eyre Peninsulas, the northern coast of Kangaroo Island, and the Mt Lofty and Flinders Ranges are bound by numerous faults with evidence for early-mid Miocene to Recent movement.

Figure 6. Photograph of steep, faulted contact between Cambrian metamorphosed shales and Quaternary conglomerates from the Willunga Fault Zone. The Willunga Fault is one of the major faults that bounds the Mt Lofty Ranges and St Vincent Basin. Cliff height is approximately $\sim 50 \mathrm{~m}$. Photograph taken in Cactus Canyon, inland of Sellicks Beach, SA (approximate location $35^{\circ} 20^{\prime} 43.96 " \mathrm{~S}$, I43I I'I 3.99"E).

Figure 7. Part of seismic line 92-13 from the southeastern margin of the St Vincent Basin. The thin Cenozoic succession of the basin shows evidence for mild deformation, with a series of monoclines located above reactivated $\sim S E-$ dipping reverse faults within the underlying Cambrian succession. See Fig. 5 for location. Seismic data provided by PIRSA.

Figure 8. Map showing locations of post-breakup faults and folds in the Otway, Torquay, Bass and Gippsland basins (compiled from various sources). Note that the majority of post-breakup structures trend $\sim N E-S W$, approximately orthogonal to the regional maximum horizontal stress orientations that have been obtained for the western Otway, eastern Otway and Gippsland basins (Nelson et al., 2006). Note also that some post-breakup structures in the western Otway Basin are associated with substantial (i.e. $>$ I km) mid-Eocene exhumation, whilst some structures in the eastern Otway Basin (particularly around the Otway Ranges) are associated with major late Miocene-Pliocene exhumation. Exhumation estimates are based on both published (e.g. Cooper and Hill, 1997; Duddy and Erout, 200I; Duddy et al., 2003; Green et al., 2004; Holford et al., 2010) and unpublished apatite fission track and vitrinite reflectance data. BA, Barracouta Anticline; BaA, Baragwanath Anticline; FHA, Ferguson Hill Anticline; KF; Kingfish Anticline; MiA, Minerva Anticline; MoA, Morum Anticline; NA, Nerita Anticline RD, Rosedale Fault.

Figure 9. Regional seismic line 137-05 from the Otway Basin. Mapping of intra-Cenozoic unconformities provides evidence for multiple increments of fold growth, such as during the mid-Eocene around Morum-I (consistent with thermal history data from that well), with progressively younger folding observed towards the southeast. Folding within the Cenozoic succession is primarily related to contractional reactivation of Cretaceous normal faults, though reverse displacements have been insufficient to offset prior normal displacements. Seismic data provided by PGS (SAMDA).

Figure 10. Evidence for post-breakup reverse faulting near the Otway Ranges (see Fig. 8 for location). A) Photograph of small, low angle $\left(\sim 40^{\circ}\right)$ reverse fault within cliffs of mid-late Miocene Port Campbell Limestone at Twelve Apostles, Victoria. Fault dips approximately towards $\sim$ E-SE and reverse motion is inferred from small offsets visible at the top of the cliff and within thin grey clayey layers within the cliff face. Cliff face is approximately $\sim 40 \mathrm{~m}$ high. The fault must have formed within the past $\sim 10$ Myr (approximate location $\left.38^{\circ} 39^{\prime} 52.57^{\prime \prime S}, 143^{\circ} 6^{\prime} \mid 4.38^{\prime \prime E}\right)$. B) Photograph of small, high angle $\left(\sim 60^{\circ}\right)$ reverse fault within small quarry near Princetown, Victoria. Fault dips towards $\sim \mathrm{N}$ and is hosted within highly ferruginised sandstones of the Pebble Point Formation (Wangerrip Group, mid-Palaeocene). High angle of fault suggests that it could have initiated as a normal fault and subsequently accrued reverse displacement. Cliff height $\sim 10 \mathrm{~m}$ (approximate location $38^{\circ} 43^{\prime} 0.5$ I"S. I $43^{\circ} \mathrm{II}$ 'I3.99"E).

Figure I I. Seismic line OS90A-I3 from the Torquay sub-basin. Seismic line shows evidence for mid-Eocene deformation on the basis of angular unconformity between the Eastern View Group and Demons Bluff Group, early Oligocene deformation based on the observation of onlap of lowermost Torquay Group sediments onto the folded top Anglesea Siltstone (Demons Bluff Group) horizon tested by Wild Dog-I, and late Miocene-Pliocene deformation, based on folding of Torquay Group sediments. See Fig. 8 for location. Seismic data provided by PGS (SAMDA). 
Figure 12. Cross section of the western limb of the Anglesea Syncline at the Anglesea coal mine, Torquay sub-basin, constrained by multiple bore observations. Section provides evidence for multiple Eocene unconformities and mid-Eocene deformation. See Fig. 8 for location. Modified after Holdgate et al. (200I)

Figure 13. Seismic line 90-27 from the Cormorant Trough, western Bass Basin (Cape Wickham sub-basin). This is the largest postbreakup compressional structure in the Bass Basin, and inversion has been dated as mid-late Miocene (Blevin et al., 2005). See Fig. I for location. Seismic data provided by PGS (SAMDA).

Figure 14. Seismic line G92A-3070 from the northwest Gippsland Basin. The Flying Fish-I well tested an asymmetric, NW-verging anticline formed following movement on a high-angle SE-dipping fault. Onlap of early Miocene reflections onto the Top Latrobe Group attests to Oligocene-early Miocene deformation, whilst folding of base Pliocene horizon constrains further deformation with the past $\sim 5$ Myr (Dickinson et al., 200I). See Fig. 8 for location. Seismic data provided by PGS.

Figure 15. Map showing observed and predicted maximum horizontal stress orientations along the southern Australian margin (Reynolds et al., 2002, 2003) and highlighting the presence of a number of post-breakup deformation provinces, with the intensity of deformation (i.e. faulting, seismicity) in each possibly related to the thermal structure of the underlying crust and lithosphere. 


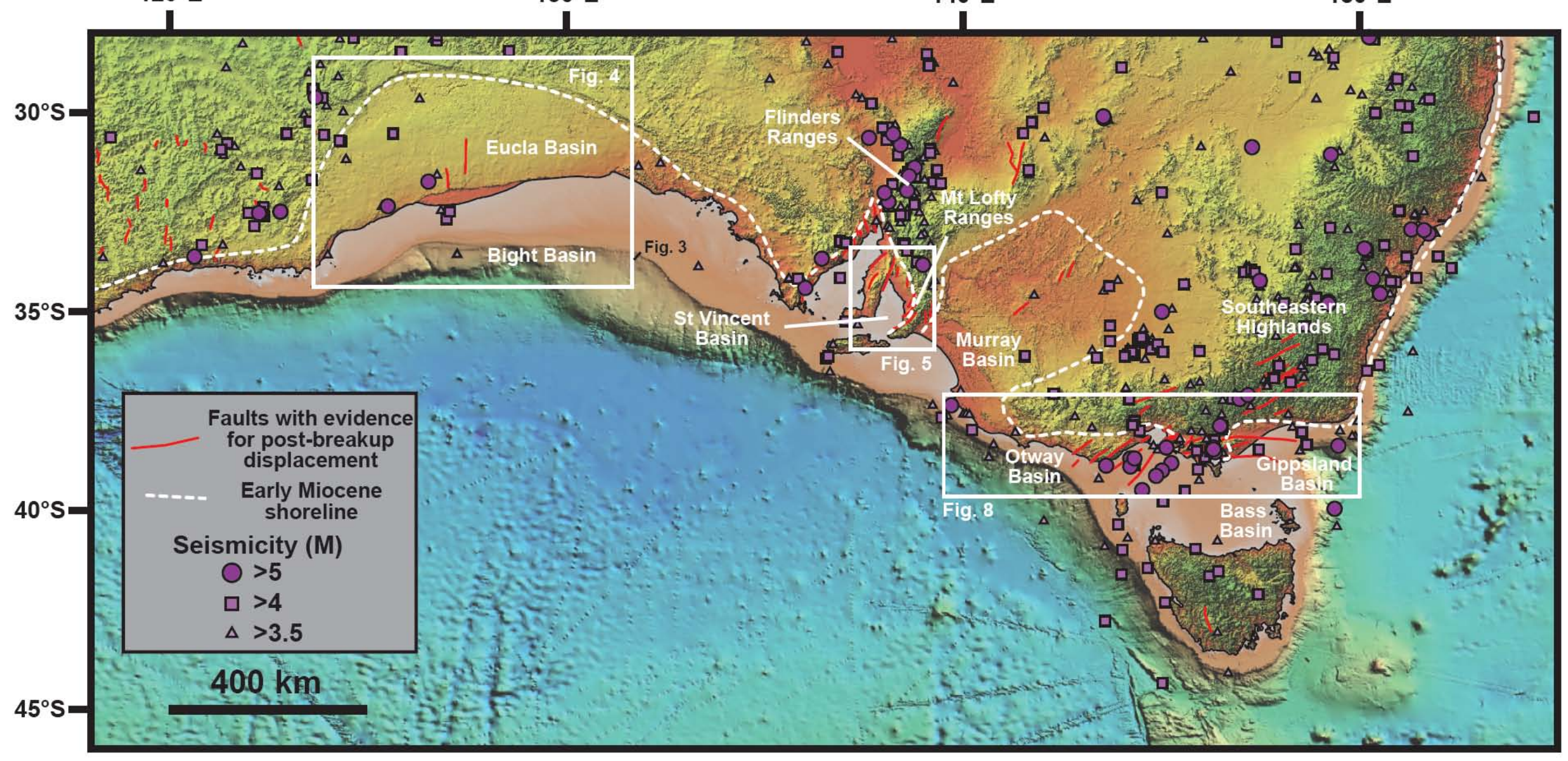




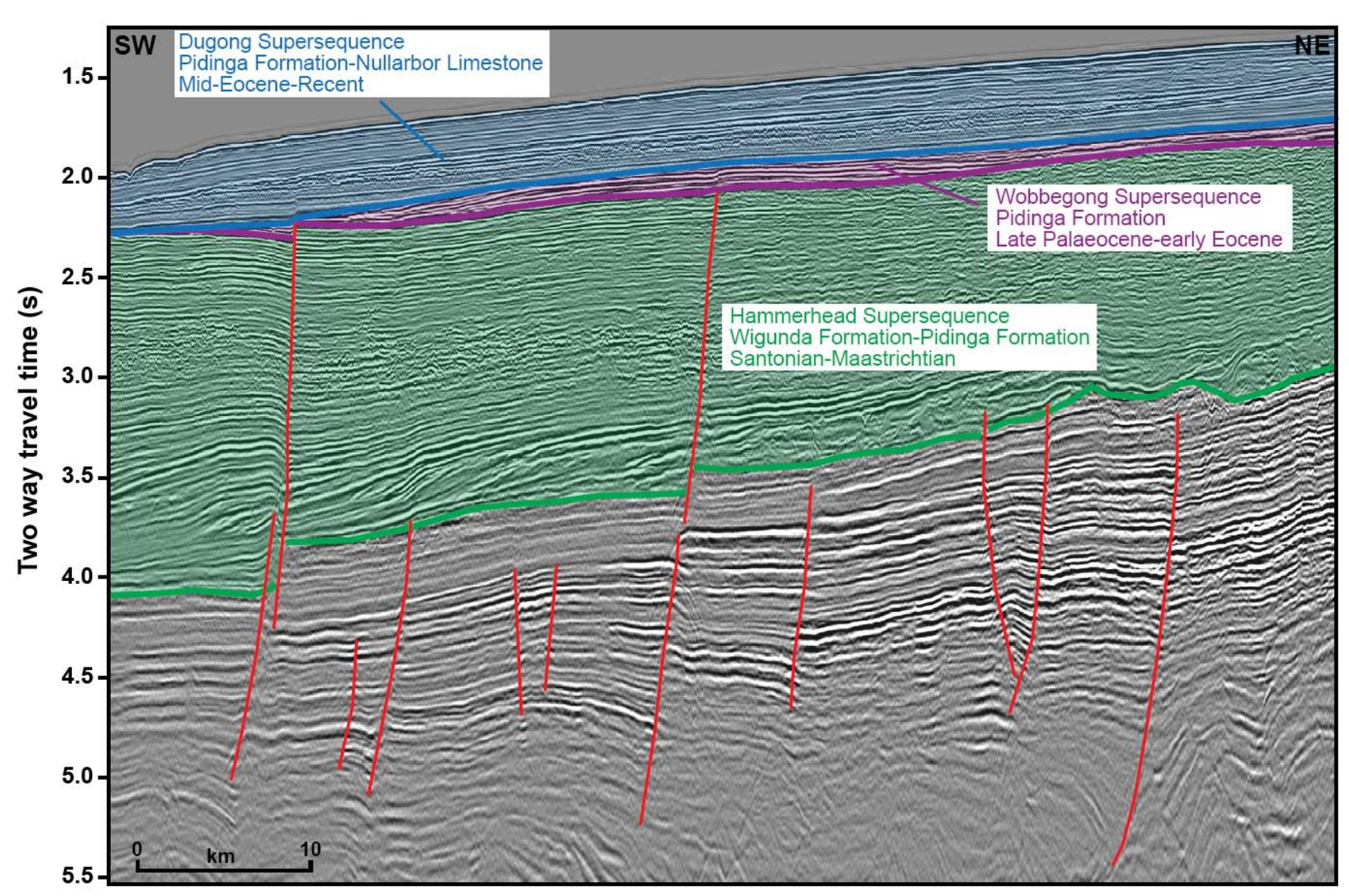




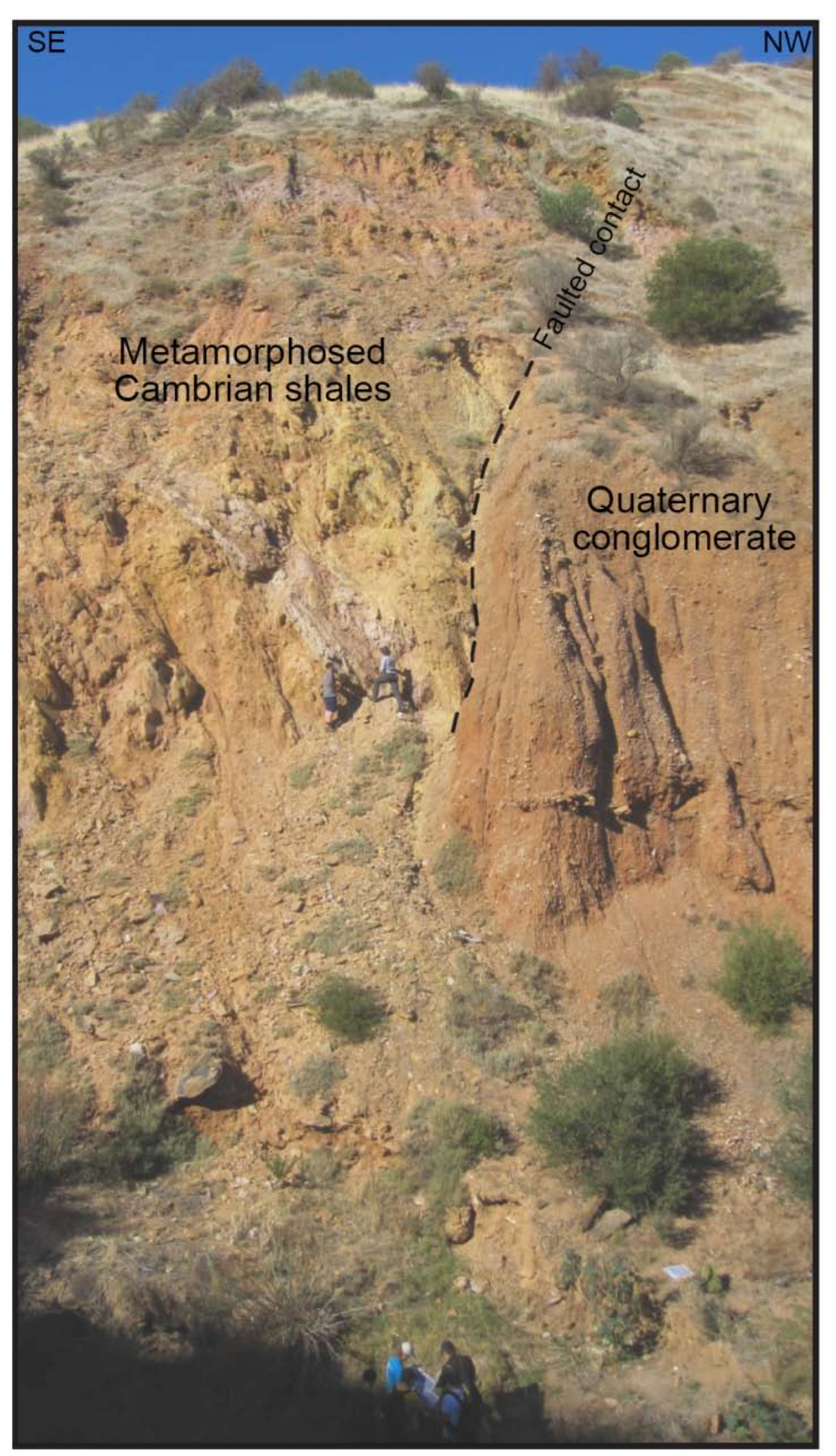




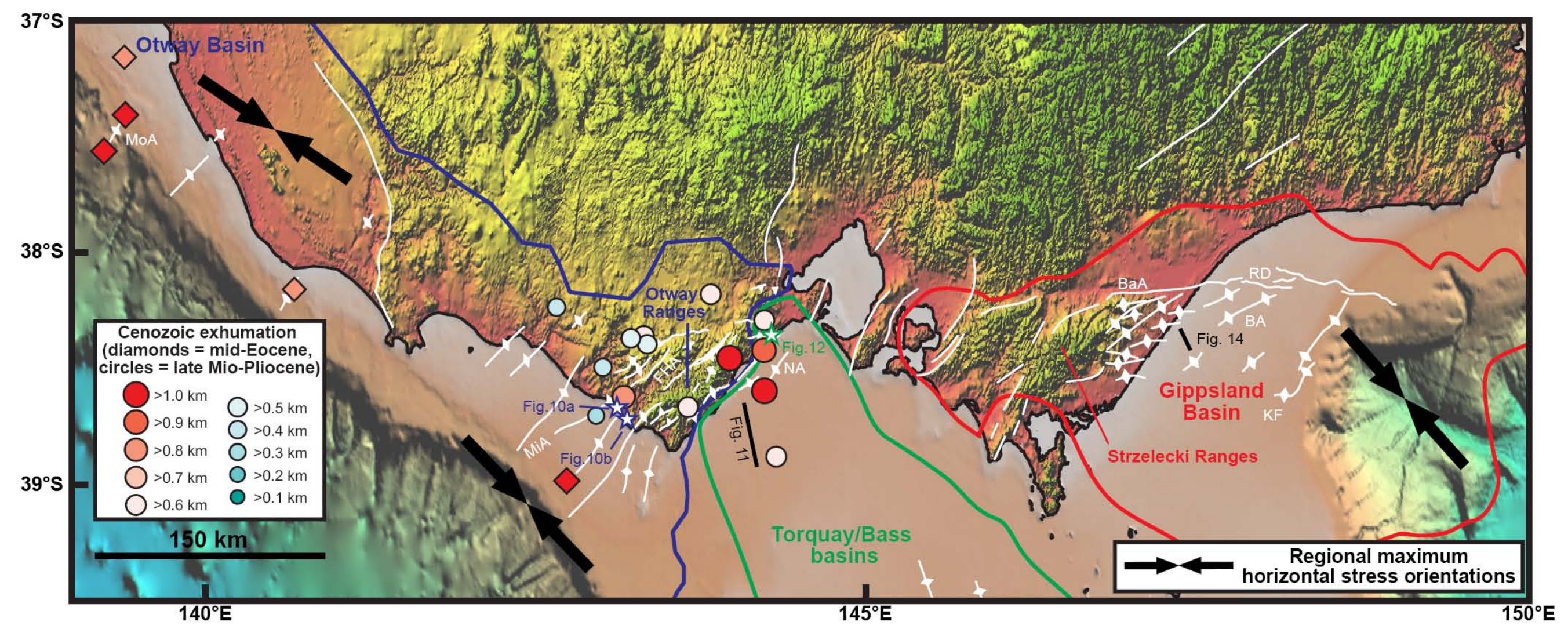




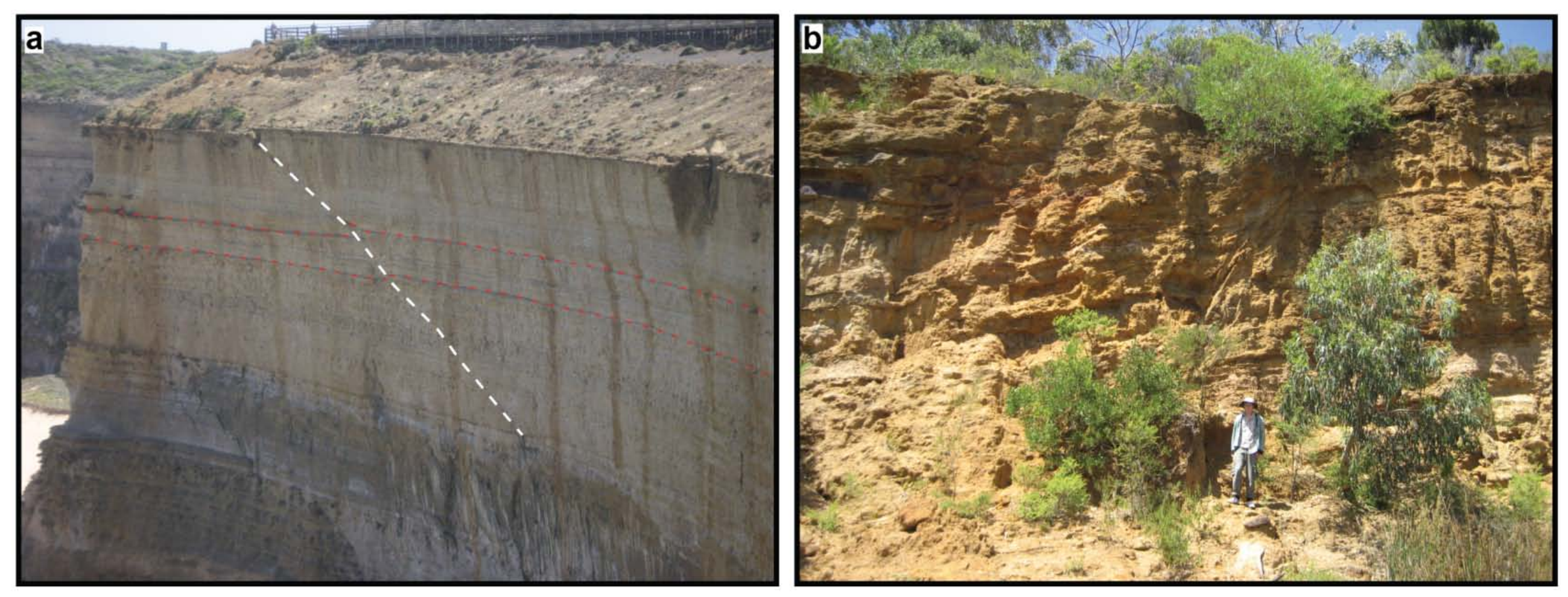




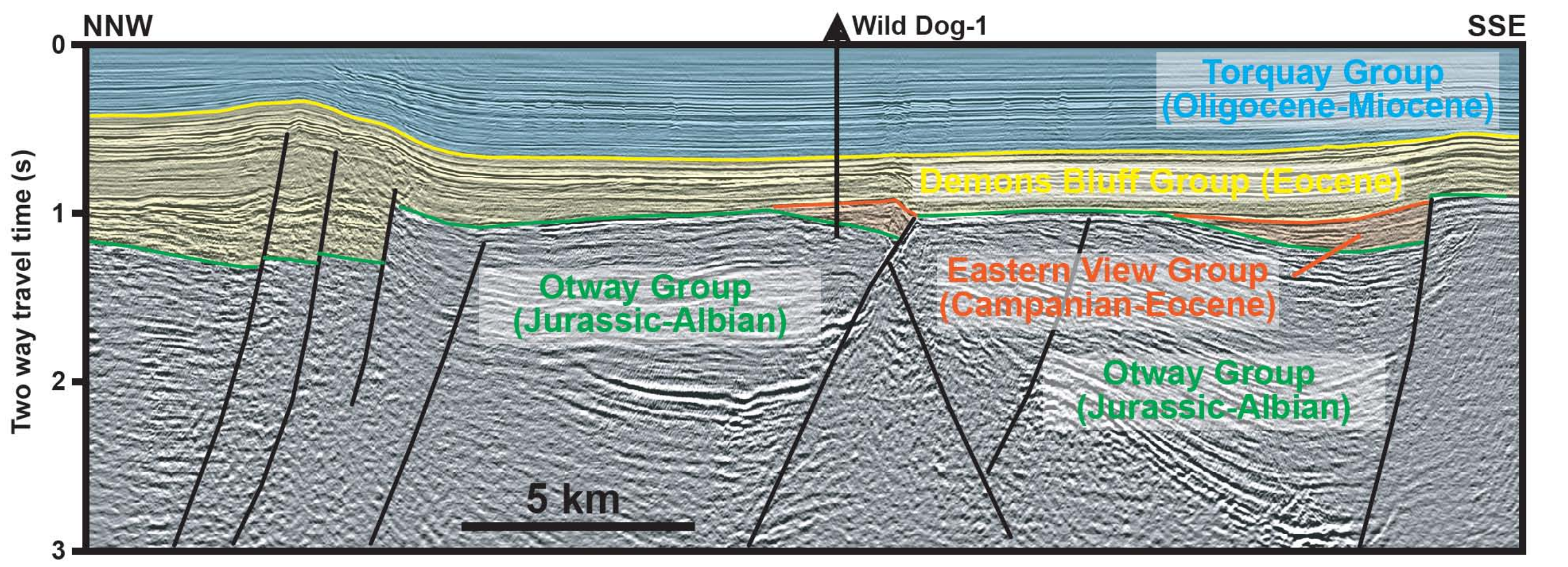




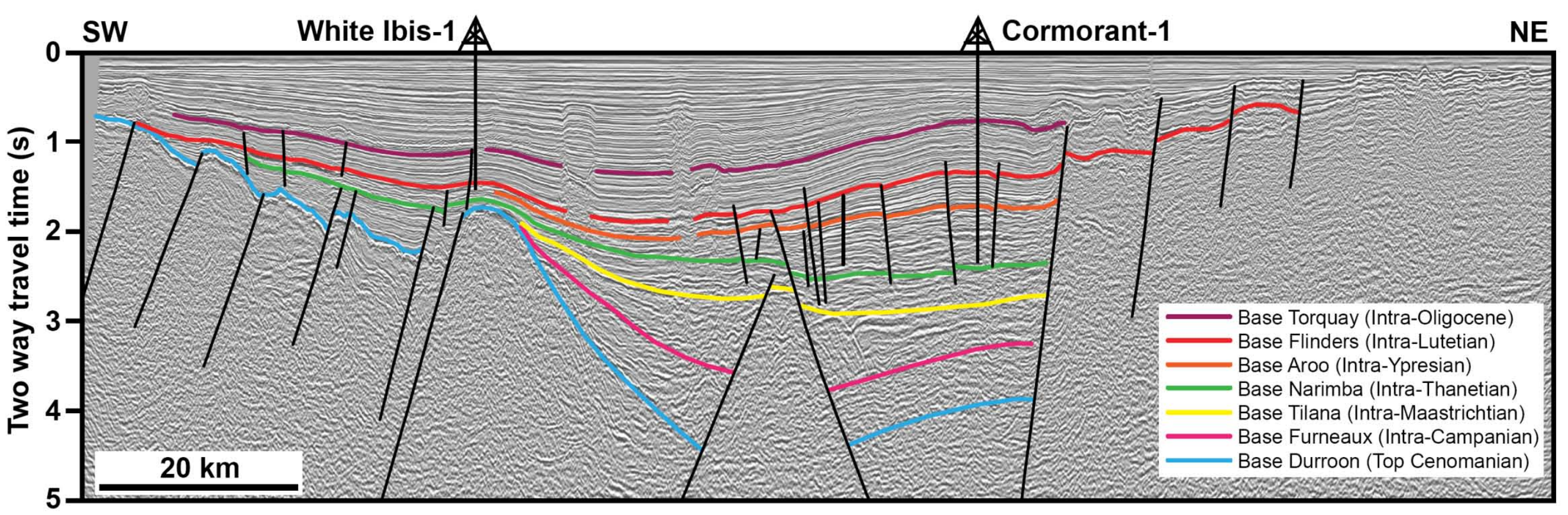



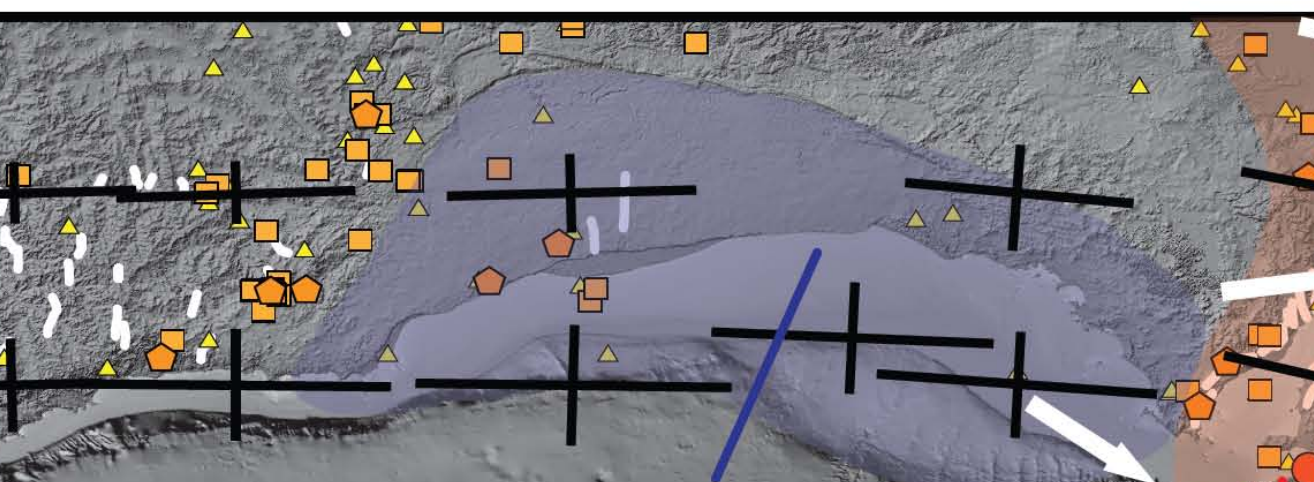